\title{
Strategic Delays and Clustering in Hedge Fund Reported Returns
}

\author{
George O. Aragon and Vikram Nanda*
}

\begin{abstract}
We use a novel database to study the timeliness of hedge fund monthly performance disclosures. Managers engage in strategic timing: poor monthly returns are reported with delay, sometimes clustered with stronger subsequent performance, suggestive of "performance smoothing." We posit that propensity to delay could reveal operational risk and/or poor managerial quality. Consistent with this, a portfolio strategy that buys (sells) funds with historically timely (untimely) reporting delivers 3\% annual-style-adjusted returns. Investor flows are lower following reporting delays, although there are potential benefits to managers from delaying reporting when performance is sufficiently poor. We conclude that timely disclosure is an important consideration for hedge fund managers and investors.
\end{abstract}

\section{Introduction}

How does information flow from hedge fund managers to investors and the broader market? Although hedge fund managers are not required to publicly disclose their performance, many do voluntarily report their monthly performance results on a regular basis to one or more public databases. Presumably, managers release performance information to garner investor attention and attract new money. A better understanding of the discretionary disclosure policies of hedge fund managers is important for several reasons. Hedge funds are significant players in financial markets, and the manner in which they choose to release (or not release) performance information to the public is important for investors and for regulators tasked with mandating greater disclosure by hedge funds.

*Aragon (corresponding author), george.aragon@asu.edu, W. P. Carey School of Business, Arizona State University; Nanda, vikram.nanda@utdallas.edu, University of Texas at Dallas and Rutgers Business School, Rutgers University. We thank Viral Acharya, Turan Bali, Nicolas Bollen (the referee), Stephen Brown (the editor), Roger Edelen, Francesco Franzoni, Mila Getmansky, Will Goetzmann, Bing Liang, Alexey Malakhov, Veronika Pool, Cristof Stahel, Cristian Tiu, and seminar participants at Arizona State University, the University of Arkansas, National University of Singapore, the University of Melbourne, Northeastern University, the U.S. Securities and Exchange Commission, Sabanci University, the University of New South Wales, the University of Massachusetts at Amherst, the Financial Markets Research Center Conference on Hedge Funds at Vanderbilt University, the 2013 European Finance Association Meetings, and the 2012 Paris Hedge Fund Conference for helpful comments. 
In the paper, we investigate the timeliness of hedge fund managers in reporting fund returns to public databases. In particular, we examine whether managers calibrate the flow of performance information by, for instance, delaying (accelerating) the disclosure of poor (good) performance, and we examine the effect this has on investor flows. From an investor's perspective, a fund's pattern of performance disclosure could be an important consideration as well. The propensity of some funds to delay the release of performance information may be indicative of underlying operational risk and/or poor management and, hence, serve as a red flag that warns of weak future performance.

We conduct our empirical tests using an extensive and novel data set that identifies the dates of return disclosures made by hedge fund managers to a public database. The data set is constructed by downloading and archiving the daily updates of the Lipper Hedge Fund Database (TASS) over several years. By monitoring the flow of information to the database on a daily basis, we can identify the exact dates of information release by hedge fund managers and, therefore, the timeliness of performance reporting. The historical updates are necessary because data vendors do not provide the specific dates on which hedge fund managers disclose new performance information to the database and provide only the most recent update of fund characteristics and the historical time series of monthly returns and assets. Our raw sample consists of 1,257 daily updates of the TASS database spanning Jan. 2009-Mar. 2014.

Our evidence strongly suggests that managers delay the release of bad news to databases. The average reporting lag (the amount of time elapsed between the end of the performance period and the subsequent disclosure to TASS) is approximately 2 weeks (16 days) and is significantly larger among poorly performing funds. Figure 1 illustrates this result graphically: A significant fraction (41\%) of disclosures remain outstanding 2 weeks after month-end, and more importantly, these delayed disclosures are associated with poor performance. The average monthly excess return based on the expanding set of reported returns from each month-end falls by about 8 basis points (bps) after the second week as managers with the more delayed performance reports are included. ${ }^{1}$ Multivariate regressions confirm that managers are slower in disclosing poor fund performance, even after controlling for fund fixed effects and time variation in the average delay among funds in the same investment style.

We acknowledge, however, that our identification strategy cannot discern all possible information channels between fund managers and existing investors beyond the discretionary disclosures to public databases such as TASS. It is possible that hedge fund managers privately convey performance results to existing investors in a timely fashion while delaying a public release. Nevertheless, managers may have incentive to delay public release of poor returns in order to protect, at least temporarily, the inflows anticipated from new investors.

We also identify several other factors that explain hedge fund manager disclosure rates. Reporting lags are greater among funds holding assets that are

\footnotetext{
${ }^{1}$ By construction, the index converges to 0 with time as all managers are included in the calculation of average excess returns. A similar index (not displayed) based on raw returns falls by 7 bps per month from the second week following month-end.
} 


\section{FIGURE 1 \\ Tracking Timeliness and Average Performance Based on Available TASS-Reported Returns by Post-Month Week}

Figure 1 plots sample averages of the cumulative percentage of all managers reporting returns to TASS for each of the 12 weeks following month-end (solid line). The figure also plots sample averages of the average style-adjusted return computed from all available returns reported to TASS for each of the 12 weeks following month-end (dashed line). Styleadjusted returns are computed as raw returns minus the average return across all funds in the same style category, using returns reported to TASS on the RDATE. The RDATE is the date of the first nonmissing monthly reported return. Averages are calculated from monthly observations over Jan. 2009-Dec. 2013.

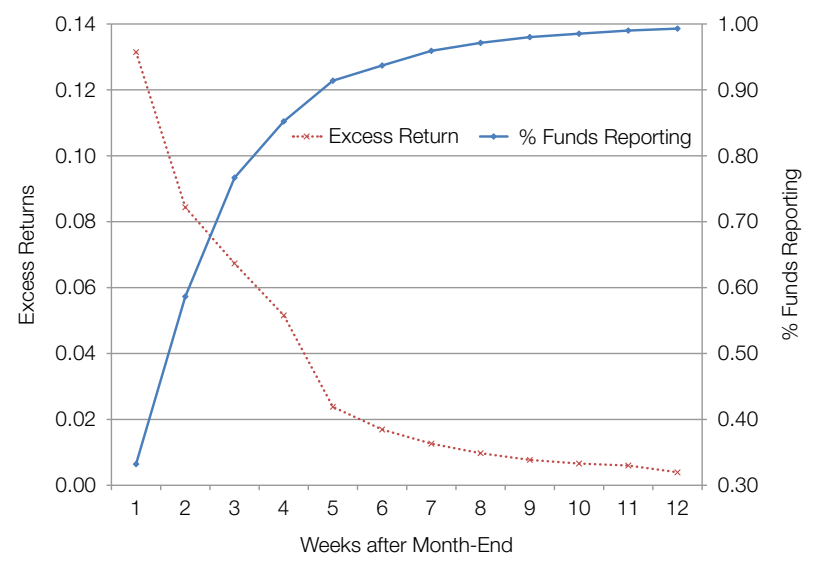

illiquid and more difficult to mark-to-market, such as funds in the style categories of convertible arbitrage and event driven (23 and 20 days, respectively) and funds with longer lockup and redemption notice periods (Aragon (2007)). The longer reporting lags among funds with more share restrictions are also consistent with lower nondisclosure costs because of fewer share redemptions. We also find slower reporting among funds that prior studies link to greater operational risk, such as offshore funds, funds without recently audited financial statements (Brown, Goetzmann, Liang, and Schwarz (2009)), and funds that display more suspicious patterns in reported returns (Bollen and Pool (2012)).

We investigate whether reporting delays are motivated, in part, by the hope for or anticipation of better news to offset the fund's poor performance. For instance, a manager may choose to report poor performance only after learning that better returns will follow and therefore that doing so will not leave a permanent stain on his or her public record. Furthermore, disclosing poor and good performance together could allow the manager to avoid some of the dissipative costs involved in liquidating assets or raising additional funds to pay for investor outflows that would arise if poor performance were reported in isolation. As we discuss later in the paper in our analysis of investor fund flows, the net benefit to the manager will also reflect the degree to which investors (or potential investors) react negatively to the reporting delay itself.

In our sample, we find many cases in which managers delay the release of return information and then report the returns at a later date along with the returns of intervening months, which we refer to as "return clusters." Such return clusters typically contain either two (about $80 \%$ of clusters) or three (about $16 \%$ ) monthly 
returns but are sometimes much longer. The earlier half of a cluster is associated with negative excess returns $(-0.24 \%$ monthly), whereas the latter half has positive excess returns $(0.21 \%$ monthly). Return clusters are therefore associated with reversals of poor performance and, in that sense, are a relatively positive outcome. We also find that the reversal patterns in return clusters are driven mainly by the subsample of young funds. This suggests that the strategic motives behind the clustering decision may be greatest among less established managers and, therefore, those with greater concern about how poor performance would impact their track record and investor flows. This would particularly be the case if they expected or hoped for better subsequent performance.

Our analysis of return clusters reveals a potentially significant delisting bias in estimates of hedge fund performance that use public databases. In particular, the return patterns associated with clusters suggest that managers may be reluctant to disclose poor outcomes unless they can offset them, at least partly, with good subsequent performance. In this case, we would be less likely to observe the returns of poorly performing funds that do not experience a reversal of performance. Making plausible assumptions and matching observed cluster patterns, we use simulations to determine that the bias in average reported excess returns from nonreporting is likely to be about $2-4$ bps per month or an annualized bias of 24-48 bps. ${ }^{2}$

We next investigate whether the timeliness of reporting predicts future fund performance. Prior studies find that operational risk, such as the failure of operational, control, and accounting systems, is associated with poor performance. ${ }^{3}$ Therefore, given our findings (discussed previously) that link reporting lags to operational risk, we might expect a negative relation between reporting lags and future performance. We uncover a strong negative relation between the historical timeliness of hedge funds' public reporting and future excess returns. A "real-time" portfolio tracking the most timely hedge funds (i.e., bottom quintile of historical reporting lags) delivers average excess returns of $0.04 \%$ per month, compared with $-0.18 \%$ for the portfolio of the least timely hedge funds. The difference, an average of $0.23 \%$ per month, is significant and also quite stable over time: The Q1-Q5 excess return spread is positive in 43 of the 57 months in our sample. We also obtain similar results from alternative performance benchmarks and month-by-month cross-sectional regressions that control for other known predictors of hedge fund performance. In addition, when we repeat our analysis on a "holdout" sample of funds of hedge funds (FoFs), the estimated Q1-Q5 return spread nearly doubles $(0.42 \%$ per month). We conclude that the timeliness of hedge fund manager reporting has significant investment value for fund investors.

Finally, we study whether fund investor flows are related to the timeliness of disclosures. Bollen and Pool (2009) and Agarwal, Daniel, and Naik (2011) find that hedge fund flows are sensitive to past fund performance, including the number of prior negative monthly returns. Therefore, fund managers may have an

\footnotetext{
${ }^{2}$ Our evidence of a delisting bias in hedge fund returns is consistent with recent studies that report a decline in fund performance after hedge funds stop reporting to a commercial database (Aiken, Clifford, and Ellis (2013), Agarwal, Fos, and Jiang (2013)).

${ }^{3}$ Brown, Goetzmann, Liang, and Schwarz (2008), (2009), for example, develop an operational risk measure using hedge fund manager filings of Form ADV.
} 
incentive to delay poor performance if doing so weakens the flow-performance relation and helps preserve capital. Managers must weigh these benefits, however, with the possibility that nondisclosure itself would be interpreted negatively by investors. Consistent with a negative-performance signal from nondisclosure, we find that net fund flows are significantly lower following delays in disclosure. At the same time, publicly releasing the poor-performance information (in a timely fashion) may have led to even lower net flows, given that disclosure delays are found to be associated with a significantly lower flow-performance sensitivity. It appears, therefore, that the manager of a fund with a sufficiently poor performance may be better off, on the margin, by delaying information disclosure. In particular, our regression estimates suggest that reporting delays appear to be justified for a manager with fund performance less than or equal to approximately 1 standard deviation below the mean.

Several recent studies focus on the disclosure strategies of hedge funds and, in particular, the issue of distortion of return information. Getmansky, Lo, and Makarov (2004) show that a fund's exposure to illiquid assets can make reported returns look "smoother" than true economic returns and can create downward biases in measured return volatility. This performance smoothing can result from nonsynchronous trading of the underlying assets or deliberate behavior by the manager. Bollen and Pool (2008) extend this model to allow for conditional smoothing such that a manager's smoothing behavior is more prevalent when fund performance is poor. ${ }^{4}$ Our analysis contributes to this literature by providing direct evidence that delaying the release of information is a mechanism through which some hedge fund managers strategically affect reported returns.

Agarwal, Jiang, Tang, and Yang (2013) and Aragon, Hertzel, and Shi (2013) study the mandatory portfolio disclosures of Section 13(f) hedge fund managers and find that confidentially held stock positions, which are typically conferred a special privilege to delay disclosure, contain valuable stock price information over the confidential period. In contrast, we study the voluntary return disclosures of hedge fund managers to a public database and find that reporting delays are associated with worse performance. An important difference between the two settings is that in the former, managers must seek formal permission from regulatory authorities to delay the disclosure of 13(f) security positions, whereas delays in disclosure in the latter case are entirely discretionary. Our results suggest that the information content of delays in disclosure depends critically on the specific disclosure environment.

Our paper also adds to the literature on hedge fund flows and performance. For example, prior studies focus on the shape of the flow response to past performance and its interactions with investor share restrictions. ${ }^{5}$ Our findings indicate that both the level and shape of the flow response are significantly related to the speed with which managers disclose information about fund performance. Prior studies also find that fund performance is related to fund-level variables, including lockup provisions (Aragon (2007)), managerial incentives (Agarwal, Daniel, and

\footnotetext{
${ }^{4}$ See also Bollen and Pool (2009), (2012), Agarwal et al. (2011), Cassar and Gerakos (2011), and Patton, Ramadorai, and Streatfield (2013).

${ }^{5}$ See, for example, Goetzmann, Ingersoll, and Ross (2003), Agarwal, Daniel, and Naik (2004), Baquero and Verbeek (2009), and Ding, Getmansky, Liang, and Wermers (2009).
} 
Naik (2009)), restatements of prior returns (Patton et al. (2013)), and past performance. ${ }^{6}$ Our evidence shows that in addition to these factors, fund performance is related to managerial delays in reporting fund returns.

Finally, there exists a fairly well-developed literature on the disclosure policies of firms. ${ }^{7}$ The regulatory regimes under which firms and hedge funds operate is, of course, radically different. Whereas corporate managers have some limited discretion in the timing and quality of the information released, they are governed by myriad rules and requirements that come from the U.S. Securities and Exchange Commission (SEC), generally accepted accounting principles (GAAP), stock exchanges, the threat of shareholder lawsuits, and other sources. Hedge fund managers, in contrast, are largely free to set their own policies for disclosure to public databases. Our analysis shows that although some managers do engage in timing the public release of performance information, there are market consequences of delaying the release of information once the fund has (implicitly) committed to providing the information through a data provider such as TASS.

The remainder of the paper is organized as follows: Section II discusses our hypotheses and empirical predictions. Section III describes the data used in the empirical analysis. Our main empirical results are presented in Section IV, and Section V concludes.

\section{Hypotheses and Empirical Predictions}

In this section, we provide a succinct discussion of our hypotheses. As noted earlier, hedge funds are not generally required to publicly disclose their performance information. Yet many managers do provide their performance and other information on a regular basis to publicly available databases such as TASS. Presumably, the dissemination of performance information serves as a means of attracting new investors and funds. Hedge funds, however, retain considerable leeway in terms of when they release their performance information. ${ }^{8}$

The issue of interest for us is whether hedge funds are strategic in the timing of their information disclosure; that is, do managers seek to delay the release of poor performance information and accelerate the release of strong performance? Although we would expect investors to respond negatively to such a delay, a poorly performing hedge fund may still benefit, on the margin, by delaying the disclosure of its performance. For instance, the model of delayed disclosures by Acharya, DeMarzo, and Kremer (2011) would suggest that as long as there is a sufficient probability that delays are being caused by nonstrategic rather than

\footnotetext{
${ }^{6}$ See, for example, Kosowski, Naik, and Teo (2007), Boyson (2008), Fung, Hsieh, Naik, and Ramadorai (2008), and Jagannathan, Malakhov, and Novikov (2010). Prior studies also find a relation between hedge fund performance and systematic risk (Bali, Brown, and Caglayan (2011), (2012), (2013)).

${ }^{7}$ Early and influential papers on the timing of information releases, usually in the context of publicly traded firms, include those by Ross (1979), Grossman (1981), Milgrom (1981), Verrecchia (1983), and Diamond (1985).

${ }^{8}$ Hedge funds have historically been prohibited from making certain statements that would be construed as advertising to nonaccredited investors. Public databases, such as TASS, can provide a safe harbor from this rule because they sell subscriptions only to accredited investors and intermediaries. The advertising ban has recently been lifted under the 2012 Jumpstart Our Business Startups Act.
} 
strategic motives (e.g., valuation of illiquid investments), there can be an equilibrium in which poor performance corresponds to delayed disclosure.

As we have noted, the information that a hedge fund provides existing investors may differ from what is released publicly, and it is possible that in many cases existing fund investors know of a fund's poor performance, even if it is not publicly disclosed. However, funds may still have the incentive to delay releasing information to public databases in order to protect their track record and maintain new investor inflows in the near term. There are other potential benefits from delaying poor performance disclosure as well: to give the fund additional time over which to manage the liquidation of assets or to raise more capital in anticipation of net outflows. The testable prediction is as follows:

Prediction 1. To the extent that a hedge fund engages in strategic timing, the delay with which a fund releases its return information will be decreasing in the level of its performance, controlling for style and other fund attributes.

Hedge funds, as we show, will sometimes choose to release performance information in the form of a return cluster, whereby the manager delays the reporting of returns of one or more consecutive months and discloses the returns together in a subsequent month. Our conjecture is that return clusters reflect the attempts of managers to delay poor performance until they can report it together with better performance in a subsequent month. To the extent the fund seeks to overcome its prior poor performance, we would expect return clusters to exhibit performance reversals, with poor monthly performance being followed by relatively good performance. We expect that a fund that obtains a series of poor outcomes will likely stop reporting to public databases.

Prediction 2. Return clusters are expected to be associated with return reversals, with negative performance in the first part of a cluster being followed by a more positive return performance.

A fund's proclivity to delay the release of its performance information and to engage in strategic timing could be symptomatic of underlying problems, such as operational risk and low managerial quality and, hence, a predictor of poor future performance. We state the testable prediction as follows:

Prediction 3. Funds that are subject to operational risk and have lower-ability managers may also be less likely to produce performance information in a timely fashion. In this case, we would expect that even after controlling for past performance and other fund attributes, funds that are less timely in releasing information will deliver worse future performance than other funds.

Delays in releasing performance information should send a negative signal to existing and potential investors about fund performance and quality. Hence, we would expect delays to result in lower net flows into the fund. Because funds often limit redemptions by current investors, we would expect the withdrawals to be greater when there are fewer such restrictions. A fund that does poorly would choose to delay disclosure only if it expected the negative consequences of delay to be less than those of reporting its realized returns. This suggests that fund managers will be more willing to delay disclosure when there are more restrictions on 
investor withdrawal and when fund performance is worse than a certain threshold. Thus, we can state the following:

Prediction 4. A delay in the release of performance information will lead to investors having a poorer assessment of the fund manager's ability and to lower net fund flows. However, funds that perform sufficiently poorly will still have the incentive to delay information disclosure.

\section{Data and Summary Statistics}

In this section we describe the data used in the empirical analysis, discuss sample selection criteria, and provide summary statistics.

\section{A. TASS Database}

Our main data source is the Lipper Hedge Fund Database (TASS). Although hedge funds are generally not required to make public disclosures, many funds voluntarily report historical performance and other information to commercial data vendors. ${ }^{9}$ TASS is a leading data vendor and is widely featured in the hedge fund literature. Performance figures are reported by fund managers to the database, which is updated every weekday and made available for download on a daily basis. Each update contains the most recent snapshot of fund characteristics, including the manager's compensation contract, investor liquidity restrictions, and the identity of fund service providers (e.g., management firm). Each update also contains the most recent historical time series of monthly returns and assets under management (AUM) for each individual fund, including live funds as well as those that have stopped reporting ("defunct"). ${ }^{10}$

The novelty of our empirical analysis is that we identify the dates on which a hedge fund manager adds new monthly returns to the database. This information is not directly provided by data vendors, but we can infer it by monitoring the daily changes in the history of reported returns. ${ }^{11}$ One complication is that the data vendor provides only the most recent update, rather than the full history of daily updates. We overcome this issue by downloading and archiving 1,257 daily updates in "real time" over Jan. 2009-Mar. 2014. Figure 2 counts the number of daily updates within each month of our collection period. ${ }^{12}$ Our raw sample

\footnotetext{
${ }^{9}$ One exception is that the SEC requires large investment managers, including hedge fund managers, to disclose certain long positions in U.S. equity securities on a quarterly basis. In addition, new regulations require hedge fund managers to disclose performance information confidentially to the SEC under provisions of the Dodd-Frank Act. See Section 13(f) of the Securities Exchange Act at: http://www.sec.gov/rules/final/2011/ia-3308.pdf.

${ }^{10}$ Additional information about the TASS data feed is provided at: http://www.lipperweb.com/ Handlers/GetDocument.ashx?documentId=4261.

${ }^{11}$ Although TASS provides the date on which each individual fund was initially added to the database (see, e.g., Aggarwal and Jorion (2010)), it does not provide the date on which each individual return was initially reported to the database. This is a key distinction that highlights the novelty of our data.

${ }^{12}$ Note that the number of updates in our sample $(1,257)$ is less than the 1,368 total weekdays over Jan. 2009-Mar. 2014. The difference is mainly explained by days where TASS does not update the database on its Web site, either due to technical problems or a lack of new information provided to the database by fund managers. The other missing updates are due to technical problems on our side in downloading the database.
} 
FIGURE 2

Number of Daily Updates of the TASS Database, by Sample Month

Figure 2 plots the number of daily updates of the TASS database in our sample for each month over our collection period (Jan. 2009-Mar. 2014). The total number of daily updates in our sample is 1,257.

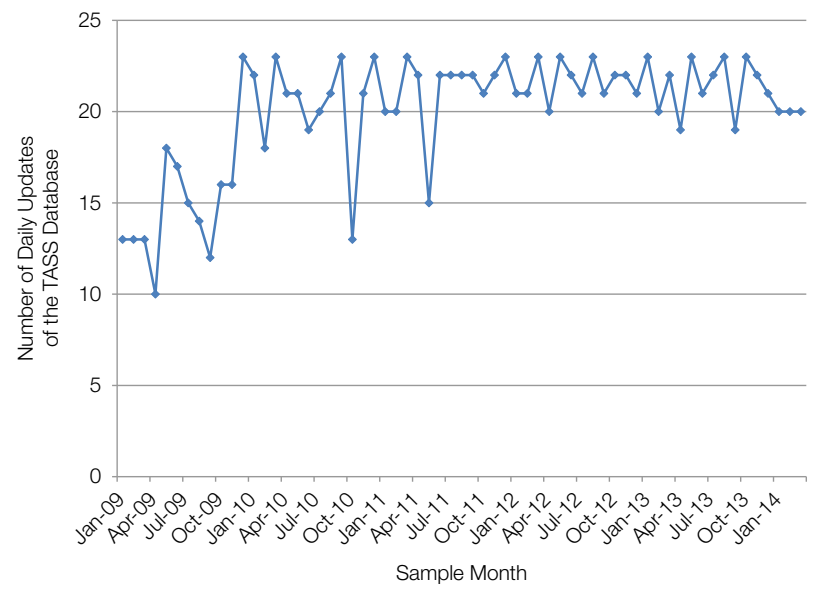

contains approximately 1.35 billion observations of monthly returns for 20,287 individual hedge funds. Compared with prior studies that use only a single TASS update, our raw sample is much larger because we are combining several updates of TASS. Therefore, for each fund, we potentially have several observations of the same monthly performance period. From the raw sample, we monitor changes in the daily updates to decipher the disclosure date of each return in the database. Specifically, we define the RDATE as the earliest date on which a return for that fund/month appears in our sample. Next, we define REPLAG (the reporting lag) for each monthly performance period as the number of days between month-end and the corresponding RDATE. After constructing the reporting lags, we then focus on the sample of 1,424,494 unique fund/month return observations.

RDATE returns often differ from returns reported in subsequent updates for the same fund and month (Patton et al. (2013)). It is plausible that later disclosures are more precise given that managers have more information about asset values. Therefore, in our analysis of fund return predictability and capital flows, we use the latest available monthly returns reported to TASS at the end of our collection period (Mar. 2014). ${ }^{13}$ We also use the end-of-collection period AUM for each fund/month observation reported to TASS. Many funds have either a partial or complete set of missing AUM values in the database. We convert the available AUM figures into U.S. dollars using fund currency codes (from TASS) and the corresponding monthly exchange rates from DataStream and the Federal Reserve Bank of St. Louis, and we then winsorize the AUM observations at the 1st and 99th percentiles.

\footnotetext{
${ }^{13}$ We find similar results if we instead compute flows and performance using RDATE returns.
} 


\section{B. Sample Selection}

We impose other selection criteria to focus our analysis on the strategic disclosure decisions of fund managers. In particular, we exclude all returns from each fund's earliest available snapshot in our sample. This criterion has two effects. First, it excludes all returns that were reported to the database prior to the start of our collection period and therefore are returns for which we cannot accurately measure the RDATE. Second, for funds that are added to the database during our sample period, the criterion excludes all returns that were generated during the preinclusion period ("backfilled data"). ${ }^{14}$ Next, for each fund, we exclude all returns after the fund first appears in the returns graveyard database (i.e., "defunct"). This is not to say that we exclude defunct funds, however, because many of our sample funds are ultimately classified as defunct by the end of our sample period. The resulting sample contains 379,656 observations for 13,453 individual hedge funds.

We also detect a few situations in which a manager is already reporting to the database but subsequently adds monthly performance data from an earlier period, thereby creating backfilled data. We therefore drop all observations from any performance period that precedes the most recent performance period on which the fund has reported. We also exclude all returns corresponding to months before Jan. 2009 or after Dec. 2013. We do this to avoid any effects of our collection period on the distribution of reporting lags. The concern is that because our collection procedure begins at the start of 2009, we do not observe pre-2009 returns that were reported prior to 2009, which could lead to longer average reporting lags among the pre-2009 returns that we do observe. Similarly, because our collection procedure ends in Mar. 2014, we do not observe the delayed returns for the final months in our collection period, which could lead to shorter average reporting delays among the returns we do observe. We also drop monthly returns that are either less than $-100 \%$ or greater than $200 \%$ (likely misstatements), and we exclude funds that do not report the identity of the management firm or investment advisor. The resulting sample contains 356,962 observations for 12,916 individual hedge funds.

Last, we exclude from our analysis all funds in the FoFs style category. This is mainly to avoid any confounding relation between fund performance and reporting lags, given the evidence that FoFs have lower returns than other funds. In addition, because they are portfolios of underlying hedge funds, it is plausible that FoFs will have larger-than-average reporting lags. ${ }^{15}$ However, as we argue later, FoFs provides a useful holdout sample that we use to show the robustness of our main findings.

\footnotetext{
${ }^{14}$ The backfilled period might represent a period of fund incubation, during which multiple funds are managed with the purpose of generating a favorable track record and are not generally open to the public (see, e.g., Evans (2010)). Alternatively, the observations could correspond to a period during which the fund was reporting to an alternative (non-TASS) commercial database.

${ }^{15}$ Prior studies find that FoFs underperform other hedge fund style categories and attribute this underperformance to the double layer of manager fees (Brown, Goetzmann, and Liang (2004)), misspecified benchmarks (Ang, Rhodes-Kropf, and Zhao (2008)), and self-selection based on lower manager skill (Agarwal and Kale (2007)).
} 
Our final sample contains 208,828 monthly returns contained in 197,138 separate disclosures for 7,691 individual hedge funds, corresponding to monthly performance periods in years 2009 (35,662), 2010 (38,064), 2011 (45,529), 2012 $(46,944)$, and $2013(42,629)$.

\section{Other Fund Variables}

Our analysis features several other fund-level variables. AGE is defined as the number of years between the monthly performance period and the fund's inception date. THIRD_PARTY is an indicator variable that equals 1 if the fund's administrator is different from either the fund's management firm or investment advisor. We also use information on the fund's incentive (INC_FEE) and management fees (MGMT_FEE), lockup period (LOCKUP), and redemption notice periods (NOTICE) and dummy variables for whether the fund's manager invests personal capital in the fund (PERSCAP) and whether the fund reports AUM to the TASS database (D_AUM), uses a high-water mark to calculate performance fees (HWM), has been audited within the last 2 years (AUDITED), and accepts capital through managed accounts (ACCEPTS). Aggarwal and Jorion (2012) argue that funds accepting capital through managed accounts provide greater transparency to fund investors. We also construct a dummy variable that equals 1 if the fund is domiciled in an offshore financial center (OFFSHORE) according to the International Monetary Fund and Financial Stability Forum (Zoromé (2007)). ${ }^{16}$

Last, we consider other variables that prior studies link to the quality of returns data reported by hedge fund managers. We use the first principal component (FLAGSPC) of 11 data quality and suspicious return variables that are considered by Bollen and Pool (2009), (2012) and Agarwal et al. (2011). We also include a dummy variable (RESTATE) that equals 1 if the fund restated at least one return in the past. We detail the sources/construction of these variables in the Internet Appendix (available at www.jfqa.org). ${ }^{17}$

\section{Summary Statistics}

Table 1 shows that our key variable, REPLAG, has a sample mean of approximately 2 weeks (16 days). However, from Figure 1, we see that the reporting lags can be much greater, with roughly $40 \%$ of the returns remaining unreported even 2 weeks after the performance period. The average value of REPLAG falls over our sample period from 18 days in 2009 to 17 days in 2013, although the trend is

\footnotetext{
${ }^{16}$ Where possible, we match fund characteristics with monthly returns using the characteristics reported to TASS at the corresponding month-end. For some fund/month observations, data on fund characteristics are not reported to TASS, and we therefore use the last available fund characteristics reported in prior months. In fewer cases, data on fund characteristics are not reported to TASS in either the current or previous months, and we therefore use the fund characteristics reported in the earliest subsequent disclosure. We also use the TASS-provided company identification numbers to identify families and administrators.

${ }^{17}$ The 11 variables represent suspicious patterns in reported returns and are based on having too many zero returns, too few negative returns, too few unique returns, the maximum run of identical returns, too many recurring return blocks of length 2 , a lack of uniformity of the second digit in returns, too few small negative returns, too much monthly return autocorrelation, significant conditional return autocorrelation, too little correlation with the Fung and Hsieh (2004) factors, and a significant December return spread (relative to non-December returns). See also Straumann (2008) and Bollen and Pool (2008).
} 
TABLE 1

Timeliness of Hedge Fund Reporting

Table 1 summarizes the reporting lags of 208,828 monthly returns over Jan. 2009-Dec. 2013 reported by hedge funds to TASS. REPLAG is the number of days between the RDATE and the end of the corresponding monthly performance period. RDATE is the date of the first nonmissing monthly reported return. Summary statistics are reported for the full sample of reporting lags, and style category and calendar year subsamples. For each subsample, the table reports the number of observations $(N)$ and the mean, standard deviation (Std. Dev.), median, and maximum (Max) reporting lag. $\% \geq 30$ is the sample frequency of whether the reporting lag exceeds 30 days. \% Clus. is the sample frequency of whether the reporting lag corresponds to a return that is reported in a return cluster.

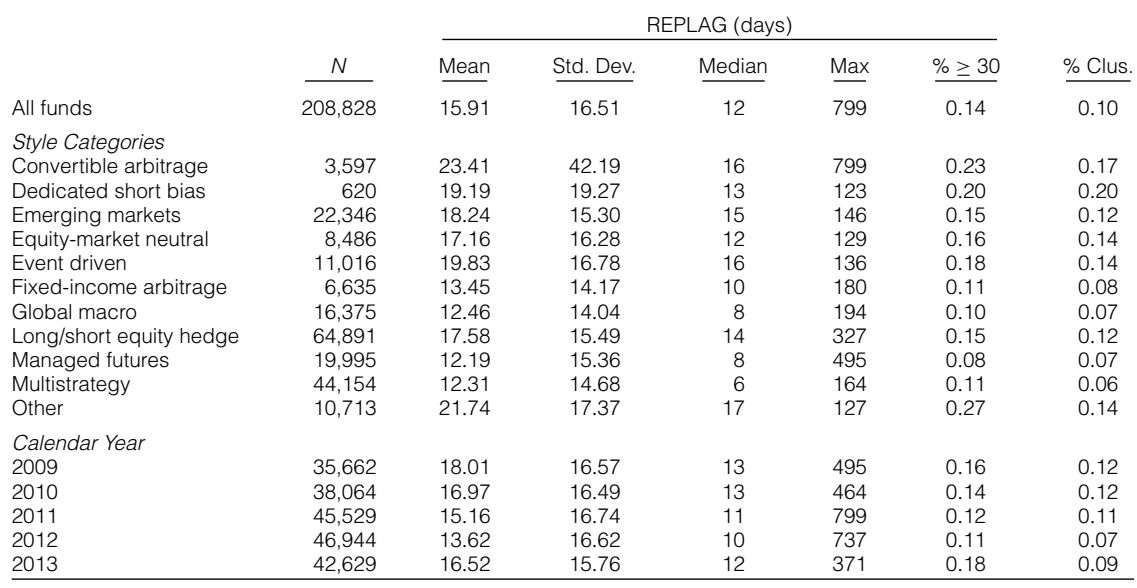

not strictly monotonic. The table also shows that reporting lags vary significantly across style categories. The most timely reporting funds belong to the managed futures (12.19 days) style category, whereas much longer average reporting lags are found among convertible arbitrage (23.41 days) and event-driven funds (19.83 days). This evidence is broadly consistent with a negative relation between timely reporting and investment strategies that involve illiquid assets (see Getmansky et al. (2004), Table 8). ${ }^{18}$ Asset liquidity is unlikely to be the only factor in explaining reporting lags, however, because there is significant within-style variation in reporting lags. Finally, Table 1 shows that $10 \%$ of all returns are reported in return clusters, that is, simultaneously with at least one other previously unreported return.

Table 2 shows summary statistics for other variables in our analysis. There are several months for which AUM was never reported to the database. Among the reported AUM observations, the mean and median are \$124 million and \$25 million, respectively. These figures are representative of those reported in other hedge fund studies; for example, Agarwal et al. (2011) report a mean and median size of \$118 million and \$29 million, respectively. The pooled average and standard deviation of monthly fund returns are $0.47 \%$ and $4.69 \%$, respectively. Despite positive average returns, the equal-weighted average of monthly fund flows over the sample period are negative, $-0.55 \%$. In comparison (not tabulated), over the same sample period, the mean and standard deviation of Standard

\footnotetext{
${ }^{18}$ The correlation between the monthly average reporting lag and the Pastor and Stambaugh (2003) liquidity measure is $-17 \%$, suggesting that longer delays coincide with lower stock market liquidity; however, the correlation is not significant at conventional levels.
} 
TABLE 2

Summary Statistics of Other Variables

Table 2 summarizes fund characteristics in our sample. RETURN is the return reported to TASS on the RDATE. AGE is the fund's age (in years) relative to the fund's inception date. AUM is the fund's assets under management (in \$millions). FLOW is an equal-weighted average of the monthly difference between the fund's asset growth and return. Flow observations are trimmed at the 1st and 99th percentiles. INC_FEE and MGMT_FEE are percentage fees corresponding to the performance and fixed components of the manager's fees, respectively. LOCKUP and NOTICE are the fund's lockup period (in months) and redemption notice period (in days), respectively. Dummy variables are summarized based on whether the fund's management firm or investment advisor is different from the fund's administrator (THIRD_PARTY); whether the fund has been audited within the last 2 years (AUDITED), is domiciled in an offshore jurisdiction (OFFSHORE), and accepts money from managed accounts (ACCEPTS); and whether the manager's fees are tied to the fund's high-water mark (HWM). PERSCAP is a dummy variable that equals 1 if the manager invests personal capital in the fund. RESTATE is a dummy variable that equals 1 if the fund has restated at least one of its returns. FLAGSSUM is the sum of 11 suspicious return flags defined in the Internet Appendix. The table reports the number of observations $(N)$, mean, standard deviation (Std. Dev.), minimum (Min), median, and maximum (Max).

\begin{tabular}{|c|c|c|c|c|c|c|}
\hline Variable & $N$ & Mean & Std. Dev. & Min & Median & Max \\
\hline \multicolumn{7}{|c|}{ Panel A. Time-Series Variables Pooled across Funds and Months } \\
\hline $\begin{array}{l}\text { RETURN } \\
\text { AGE } \\
\text { AUM } \\
\text { FLOW }\end{array}$ & $\begin{array}{l}208,828 \\
208,828 \\
142,738 \\
133,302\end{array}$ & $\begin{array}{c}0.0047 \\
5.98 \\
124.40 \\
-0.0055\end{array}$ & $\begin{array}{c}0.0469 \\
4.80 \\
289.16 \\
0.1051\end{array}$ & $\begin{array}{l}-0.9999 \\
0.08 \\
0.04 \\
-0.5439\end{array}$ & $\begin{array}{l}0.0047 \\
4.84 \\
25.30 \\
0.0000\end{array}$ & $\begin{array}{r}1.8845 \\
113.91 \\
1,966.20 \\
0.7583\end{array}$ \\
\hline \multicolumn{7}{|c|}{$\underline{\text { Panel B. Other Variables Pooled across Funds }}$} \\
\hline $\begin{array}{l}\text { INC_FEE } \\
\text { MGMT_FEE } \\
\text { HWM } \\
\text { LOCKUP } \\
\text { NOTICE } \\
\text { THIRD_PARTY } \\
\text { AUDITED } \\
\text { PERSCAP } \\
\text { OFFSHORE } \\
\text { ACCEPTS } \\
\text { RESTATE } \\
\text { FLAGSSUM }\end{array}$ & $\begin{array}{l}7,146 \\
7,663 \\
7,665 \\
7,691 \\
7,691 \\
7,323 \\
7,691 \\
7,691 \\
7,691 \\
7,691 \\
7,691 \\
5,785\end{array}$ & $\begin{array}{r}0.15 \\
0.01 \\
0.57 \\
2.37 \\
28.43 \\
0.92 \\
0.37 \\
0.17 \\
0.58 \\
0.17 \\
0.33 \\
2.11\end{array}$ & $\begin{array}{r}0.09 \\
0.01 \\
0.49 \\
6.37 \\
34.76 \\
0.27 \\
0.48 \\
0.37 \\
0.49 \\
0.37 \\
0.47 \\
1.58\end{array}$ & $\begin{array}{l}0.00 \\
0.00 \\
0.00 \\
0.00 \\
0.00 \\
0.00 \\
0.00 \\
0.00 \\
0.00 \\
0.00 \\
0.00 \\
0.00\end{array}$ & $\begin{array}{r}0.20 \\
0.02 \\
1.00 \\
0.00 \\
30.00 \\
1.00 \\
0.00 \\
0.00 \\
1.00 \\
0.00 \\
0.00 \\
2.00\end{array}$ & $\begin{array}{r}0.50 \\
0.07 \\
1.00 \\
90.00 \\
365.00 \\
1.00 \\
1.00 \\
1.00 \\
1.00 \\
1.00 \\
1.00 \\
9.00\end{array}$ \\
\hline
\end{tabular}

\& Poor's 500 Index (S\&P 500) monthly return are $1.30 \%$ and $4.57 \%$, respectively, as stock market values and liquidity recover from the financial crisis bottom. Moreover, the hedge fund industry overall shows modest growth over the sample period, both in terms of the number of funds (from 3,685 to 4,186) and aggregate assets under management (from $\$ 275$ to $\$ 285$ billion) in our sample.

In Panel B of Table 2 we summarize fund characteristics at the end of our sample period. For example, the average lockup and redemption-notice periods are 2.37 months and 28.43 days, respectively. We also find that the majority of funds (92\%) use third-party administrators, $58 \%$ of funds are domiciled in offshore financial centers, $33 \%$ of all funds have restated at least one return, and the average number of suspicious return flags equals 2.11 (out of 11).

Table 3 shows the pairwise correlations between REPLAG and other fund variables. The correlation between reporting lag and return rank is $-5 \%$, indicating that worse performance is associated with longer delays. This is the same message delivered graphically by the dashed line in Figure 1, which shows that the average return falls as later-reporting funds are included in the average. This pattern is unlikely to be explained by style-specific effects because we calculate return ranks within each style category and month.

Funds with lockup and notice periods are more likely to hold illiquid assets that are difficult to value (Aragon (2007)). This can partly explain why these funds tend to report returns more slowly than other funds. Reporting lags also 
TABLE 3

Pairwise Correlations of Reporting Delays with Fund Characteristics

Table 3 reports pairwise correlations between the fund variables considered in the analysis. Sample correlations are calculated from the raw sample of fund/month observations over Jan. 2009-Dec. 2013. RETRNK is the rank of RETURN relative to all other funds in the same month and style category. FLAGSPC is the first principal component of 11 suspicious return flags defined in the Internet Appendix. All other variables are defined in Tables 1 and 2.

\begin{tabular}{|c|c|c|c|c|c|c|c|c|c|c|c|c|c|c|c|c|}
\hline & Variable & 1 & 2 & 3 & 4 & 5 & 6 & 7 & 8 & 9 & 10 & 11 & 12 & 13 & 14 & 15 \\
\hline 1 & REPLAG & 1.00 & & & & & & & & & & & & & & \\
\hline 2 & RETRNK & -0.05 & & & & & & & & & & & & & & \\
\hline 3 & AGE & 0.02 & 0.01 & & & & & & & & & & & & & \\
\hline 4 & AUM & 0.06 & 0.02 & 0.19 & & & & & & & & & & & & \\
\hline 5 & LOCKUP & 0.14 & 0.01 & 0.05 & 0.07 & & & & & & & & & & & \\
\hline 6 & NOTICE & 0.21 & 0.02 & 0.01 & 0.17 & 0.29 & & & & & & & & & & \\
\hline 7 & INC_FEE & 0.12 & 0.02 & 0.14 & 0.12 & 0.12 & 0.23 & & & & & & & & & \\
\hline 8 & MGM̄T_FEE & 0.01 & -0.02 & -0.04 & 0.04 & -0.01 & 0.03 & 0.18 & & & & & & & & \\
\hline 9 & HWM & 0.20 & -0.01 & 0.07 & 0.13 & 0.17 & 0.31 & 0.51 & 0.08 & & & & & & & \\
\hline 10 & PERSCAP & 0.06 & 0.01 & 0.19 & 0.08 & 0.10 & 0.09 & 0.18 & 0.01 & 0.23 & & & & & & \\
\hline 11 & OFFSHORE & 0.17 & -0.05 & -0.05 & 0.15 & -0.04 & 0.20 & 0.15 & 0.10 & 0.28 & -0.03 & & & & & \\
\hline 12 & THIRD_PARTY & 0.11 & 0.00 & -0.09 & 0.04 & 0.06 & 0.17 & 0.18 & 0.07 & 0.19 & 0.03 & 0.32 & & & & \\
\hline 13 & AUDITËD & -0.07 & 0.01 & -0.32 & -0.11 & -0.10 & -0.11 & -0.12 & 0.02 & -0.18 & -0.15 & -0.01 & -0.04 & & & \\
\hline 14 & ACCEPTS & 0.06 & 0.00 & 0.14 & 0.04 & 0.07 & 0.08 & 0.16 & 0.04 & 0.21 & 0.52 & -0.01 & 0.02 & -0.13 & & \\
\hline 15 & RESTATE & 0.04 & -0.02 & 0.23 & 0.10 & 0.04 & 0.02 & 0.05 & 0.01 & 0.12 & 0.08 & 30.05 & -0.04 & -0.12 & 0.08 & \\
\hline 16 & FLAGSPC & 0.05 & 0.01 & 0.22 & 0.04 & 0.07 & 0.11 & -0.02 & -0.08 & 0.00 & 0.02 & -0.03 & -0.01 & -0.04 & 0.00 & 0.05 \\
\hline
\end{tabular}

tend to be higher among funds that have not recently been audited, are domiciled offshore, are associated with suspicious return flags (FLAGSPC, 5\%), and restate their returns. This is broadly consistent with greater reporting lags when operational risk and misreporting behavior are high. In the next section, we investigate these relationships further in a multivariate setting.

\section{Analysis and Main Results}

In this section, we use a regression model of reporting lags to study the timeliness of hedge fund manager disclosures in a multivariate setting. We also examine return clusters (i.e., daily disclosures that contain two or more returns) to shed light on whether managers delay the reporting of poor performance in anticipation of reversals from future performance. We then test whether the timeliness of reporting lags is predictive of fund performance, and we measure the costs of delay using the response of net investor flows to a lack of timeliness in performance reporting.

\section{A. Reporting Lag Regressions}

The raw data clearly suggest that several factors are associated with reporting lags. To validate these differences, we report a multivariate regression analysis in which the dependent variable is the natural logarithm of 1 plus REPLAG. We include several explanatory variables that are plausibly related to delays in reporting: the fund's within-style return rank (RETRNK); HWM and THIRD_PARTY, variables that reflect operational risk and misreporting; and the natural logarithms of 1 plus AGE, AUM, LOCKUP, NOTICE, INC_FEE, and MGMT_FEE. All models include interactions between style and month dummies, and model 1 also includes fund fixed effects. All independent variables (except dummies) are standardized to have a 0 mean and unit variance.

The results are reported in Table 4 and strongly show that managers are slower in disclosing poor fund performance. Model 1 shows a coefficient on 
TABLE 4

Multivariate Analysis of Hedge Fund Manager Reporting Lags

Table 4 reports the results from regressions of reporting lags over Jan. 2009-Dec. 2013. The dependent variable is the natural logarithm of REPLAG. HIST_RETRNK is the fund's average return rank based on all raw returns reported to TASS prior to the current RDATE. $\triangle$ HIST_RETRNK is the change in HIST_RETRNK from including the current return in the calculation of HIST_RETRNK. Raw returns are those reported TASS on the RDATE. D_AUM is a dummy variable that equals 1 if AUM is not missing from TASS for that fund/month. All other variables are defined in Tables $1-3$. Style and month interaction dummies are included in all models. Fund fixed effects are also included in model 1. Standard errors account for heteroskedasticity and clustering either at either the fund (model 1) or month (models 2-7) level. All variables (except dummies) are standardized to have a mean and unit variance of 0 . The table reports results for the observations with nonmissing values for all explanatory variables in all models. Panel A reports results for the full sample of reporting lags. Panel B reports the estimated coefficient (coef.) and corresponding $t$-statistic $(t$ (coef.)) on the fund performance variable (RETRNK or $\triangle$ HIST_RETRNK) when the delay regression is estimated separately on various subsamples of funds. Low and High subsamples correspond to observations below and above the sample median, respectively. ${ }^{*}$ and ** denote significance at the $5 \%$ and $1 \%$ levels, respectively.

Panel A. Full-Sample Reporting Lag Regressions

\begin{tabular}{|c|c|c|c|c|c|c|c|}
\hline & 1 & 2 & 3 & 4 & 5 & 6 & 7 \\
\hline RETRNK & $\begin{array}{c}-0.0214 \\
14.67^{\star \star}\end{array}$ & $\begin{array}{c}-0.0338 \\
8.23^{\star \star}\end{array}$ & $\begin{array}{c}-0.0330 \\
8.04^{\star \star}\end{array}$ & $\begin{array}{c}-0.0387 \\
9.36^{\star \star}\end{array}$ & $\begin{array}{c}-0.0362 \\
9.07^{\star \star}\end{array}$ & $\begin{array}{c}-0.0364 \\
9.19^{\star \star}\end{array}$ & \\
\hline HIST_RETRNK & & & & & & & $\begin{array}{c}-0.0586 \\
11.00^{\star \star}\end{array}$ \\
\hline$\Delta$ HIST_RETRNK & & & & & & & $\begin{array}{c}-0.0350 \\
6.25^{\star \star}\end{array}$ \\
\hline $\ln (1+\mathrm{AGE})$ & & & $\begin{array}{l}0.0034 \\
0.47\end{array}$ & $\begin{array}{l}0.0012 \\
0.29\end{array}$ & $\begin{array}{c}-0.0066 \\
1.41\end{array}$ & $\begin{array}{c}-0.0104 \\
2.56^{\star}\end{array}$ & $\begin{array}{r}-0.0107 \\
2.76^{\star \star}\end{array}$ \\
\hline D_AUM & & & $\begin{array}{c}-0.2007 \\
9.72^{\star \star}\end{array}$ & $\begin{array}{c}-0.1498 \\
11.40^{\star \star}\end{array}$ & $\begin{array}{c}-0.1394 \\
13.04^{\star \star}\end{array}$ & $\begin{array}{c}-0.1375 \\
12.49^{\star \star}\end{array}$ & $\begin{array}{c}-0.1301 \\
11.93^{\star \star}\end{array}$ \\
\hline D_AUM $\times \ln (1+A U M)$ & & & $\begin{array}{c}0.0854 \\
16.80^{\star \star}\end{array}$ & $\begin{array}{l}0.0225 \\
8.82^{\star \star}\end{array}$ & $\begin{array}{l}0.0154 \\
5.85^{\star \star}\end{array}$ & $\begin{array}{l}0.0160 \\
6.09^{\star \star}\end{array}$ & $\begin{array}{l}0.0214 \\
8.93^{\star \star}\end{array}$ \\
\hline $\ln (1+$ LOCKUP $)$ & & & & $\begin{array}{c}0.0413 \\
10.95^{\star \star}\end{array}$ & $\begin{array}{c}0.0476 \\
11.47^{\star \star}\end{array}$ & $\begin{array}{r}0.0475 \\
11.51^{\star \star}\end{array}$ & $\begin{array}{r}0.0471 \\
11.70^{\star \star}\end{array}$ \\
\hline $\ln (1+$ NOTICE $)$ & & & & $\begin{array}{l}0.2725 \\
23.20^{\star \star}\end{array}$ & $\begin{array}{r}0.2471 \\
21.61^{\star \star}\end{array}$ & $\begin{array}{c}0.2463 \\
21.26^{\star \star}\end{array}$ & $\begin{array}{r}0.2497 \\
21.50^{\star \star}\end{array}$ \\
\hline $\ln (1+$ INC_FEE $)$ & & & & $\begin{array}{l}0.0204 \\
2.77^{\star \star}\end{array}$ & $\begin{array}{l}0.0211 \\
3.05^{\star \star}\end{array}$ & $\begin{array}{l}0.0214 \\
3.01^{\star \star}\end{array}$ & $\begin{array}{l}0.0221 \\
3.15^{\star \star}\end{array}$ \\
\hline In(1 + MGMT_FEE) & & & & $\begin{array}{c}-0.0018 \\
0.53\end{array}$ & $\begin{array}{c}-0.0063 \\
1.89\end{array}$ & $\begin{array}{c}-0.0057 \\
1.69\end{array}$ & $\begin{array}{c}-0.0069 \\
1.98\end{array}$ \\
\hline HWM & & & & $\begin{array}{c}0.1343 \\
16.06^{\star \star}\end{array}$ & $\begin{array}{c}0.1066 \\
13.49^{\star \star}\end{array}$ & $\begin{array}{c}0.1076 \\
13.89^{\star \star}\end{array}$ & $\begin{array}{r}0.1050 \\
13.78^{\star \star}\end{array}$ \\
\hline PERSCAP & & & & & $\begin{array}{c}-0.0222 \\
2.88^{\star \star}\end{array}$ & $\begin{array}{c}-0.0211 \\
2.76^{\star \star}\end{array}$ & $\begin{array}{c}-0.0183 \\
2.39^{\star}\end{array}$ \\
\hline OFFSHORE & & & & & $\begin{array}{l}0.1150 \\
9.06^{\star \star}\end{array}$ & $\begin{array}{l}0.1162 \\
9.35^{\star \star}\end{array}$ & $\begin{array}{l}0.1076 \\
9.24^{\star \star}\end{array}$ \\
\hline THIRD_PARTY & & & & & $\begin{array}{l}0.0969 \\
8.42^{\star \star}\end{array}$ & $\begin{array}{l}0.0939 \\
9.41^{\star \star}\end{array}$ & $\begin{array}{r}0.1006 \\
10.51^{\star \star}\end{array}$ \\
\hline AUDITED & & & & & $\begin{array}{c}-0.1382 \\
7.30^{\star \star}\end{array}$ & $\begin{array}{c}-0.1383 \\
7.38^{\star \star}\end{array}$ & $\begin{array}{c}-0.1405 \\
7.56^{\star \star}\end{array}$ \\
\hline ACCEPTS & & & & & $\begin{array}{l}0.0391 \\
5.61^{\star \star}\end{array}$ & $\begin{array}{l}0.0397 \\
5.71^{\star \star}\end{array}$ & $\begin{array}{l}0.0386 \\
5.57^{\star \star}\end{array}$ \\
\hline RESTATE & & & & & & $\begin{array}{c}-0.0133 \\
1.07\end{array}$ & $\begin{array}{c}-0.0139 \\
1.12\end{array}$ \\
\hline FLAGSPC & & & & & & $\begin{array}{l}0.0141 \\
9.42^{\star \star}\end{array}$ & $\begin{array}{c}0.0159 \\
10.72^{\star \star}\end{array}$ \\
\hline $\begin{array}{l}\text { Observations } \\
R^{2}\end{array}$ & $\begin{array}{c}132,635 \\
0.12\end{array}$ & $\begin{array}{c}132,635 \\
0.09\end{array}$ & $\begin{array}{c}132,635 \\
0.11\end{array}$ & $\begin{array}{c}132,635 \\
0.22\end{array}$ & $\begin{array}{c}132,635 \\
0.24\end{array}$ & $\begin{array}{c}132,635 \\
0.24\end{array}$ & $\begin{array}{c}132,635 \\
0.24\end{array}$ \\
\hline $\begin{array}{l}\text { Fund fixed effects } \\
\text { Month } \times \text { style fixed effects }\end{array}$ & $\begin{array}{l}\text { Yes } \\
\text { Yes }\end{array}$ & $\begin{array}{l}\text { No } \\
\text { Yes }\end{array}$ & $\begin{array}{l}\text { No } \\
\text { Yes }\end{array}$ & $\begin{array}{l}\text { No } \\
\text { Yes }\end{array}$ & $\begin{array}{l}\text { No } \\
\text { Yes }\end{array}$ & $\begin{array}{l}\text { No } \\
\text { Yes }\end{array}$ & $\begin{array}{l}\text { No } \\
\text { Yes }\end{array}$ \\
\hline
\end{tabular}


TABLE 4 (continued)

Multivariate Analysis of Hedge Fund Manager Reporting Lags

Panel B. Subsample Analysis of Key Panel A Coefficients

\begin{tabular}{|c|c|c|c|c|c|c|c|}
\hline \multirow[b]{2}{*}{ Subsample } & \multirow[b]{2}{*}{$N$} & \multicolumn{2}{|c|}{$\begin{array}{l}\text { Model 1: } \\
\text { RETRNK }\end{array}$} & \multicolumn{2}{|c|}{$\begin{array}{l}\text { Model 6: } \\
\text { RETRNK }\end{array}$} & \multicolumn{2}{|c|}{$\begin{array}{c}\text { Model 7: } \\
\Delta \text { HIST_RETRNK }\end{array}$} \\
\hline & & Coef. & $t$ (coef.) & Coef. & $t$ (coef.) & Coef. & $t$ (coef.) \\
\hline Convertible arbitrage & 2,335 & -0.0031 & 0.26 & 0.0105 & 0.65 & 0.0246 & 1.02 \\
\hline Dedicated short bias & 436 & 0.0133 & 0.48 & 0.0336 & 0.81 & 0.0262 & 0.39 \\
\hline Emerging markets & 16,232 & -0.0233 & $5.57^{\star \star}$ & -0.0436 & $5.35^{\star \star}$ & -0.0526 & $4.98^{\star \star}$ \\
\hline Equity-market neutral & 6,139 & -0.0345 & $4.52^{\star \star}$ & -0.0430 & $3.55^{\star \star}$ & -0.0244 & 1.90 \\
\hline Event driven & 7,431 & -0.0365 & $4.88^{\star \star}$ & -0.0502 & $4.47^{\star \star}$ & -0.0394 & $2.67^{\star \star}$ \\
\hline Fixed-income arbitrage & 3,795 & -0.0353 & $3.64^{\star \star}$ & -0.0837 & $6.76^{* *}$ & -0.0596 & $5.00^{* *}$ \\
\hline Global macro & 8,318 & -0.0102 & $2.12^{\star}$ & -0.0291 & $2.56^{\star}$ & -0.0365 & $2.73^{\star \star}$ \\
\hline Long/short equity hedge & 47,069 & -0.0250 & $9.95^{\star \star}$ & -0.0302 & $5.18^{* *}$ & -0.0317 & $3.52^{* \star}$ \\
\hline Managed futures & 13,329 & -0.0204 & $4.43^{* *}$ & -0.0255 & $2.08^{*}$ & -0.0075 & 0.51 \\
\hline Multistrategy & 21,074 & -0.0072 & $2.46^{*}$ & -0.0255 & $2.70^{\star *}$ & -0.0230 & 1.98 \\
\hline Other & 6,477 & -0.0447 & $5.46^{\star \star}$ & -0.0734 & $6.35^{\star *}$ & -0.0687 & $3.42^{\star \star}$ \\
\hline OFFSHORE $=0$ & 43,916 & -0.0238 & $8.99^{\star \star}$ & -0.0274 & $7.01^{* \star}$ & -0.0218 & $3.82^{* \star}$ \\
\hline OFFSHORE $=1$ & 88,719 & -0.0205 & $11.78^{\star *}$ & -0.0376 & $6.62^{\star *}$ & -0.0375 & $5.65^{* \star}$ \\
\hline $\mathrm{ACCEPTS}=0$ & 106,296 & -0.0210 & $13.11^{\star \star}$ & -0.0365 & $7.61^{\star \star}$ & -0.0334 & $5.30^{\star \star}$ \\
\hline ACCEPTS $=1$ & 26,339 & -0.0240 & $6.90^{\star *}$ & -0.0314 & $5.94^{* *}$ & -0.0364 & $5.29^{* *}$ \\
\hline THIRD_PARTY $=0$ & 8,877 & -0.0142 & $2.54^{\star}$ & -0.0190 & $2.41^{*}$ & -0.0099 & 0.92 \\
\hline THIRD_PARTY $=1$ & 123,758 & -0.0219 & $14.53^{\star \star}$ & -0.0388 & $9.34^{\star *}$ & -0.0382 & $6.62^{\star \star}$ \\
\hline RESTATE $=0$ & 82,696 & -0.0195 & $10.77^{\star \star}$ & -0.0308 & $8.26^{\star \star}$ & -0.0277 & $5.70^{* \star}$ \\
\hline RESTATE $=1$ & 49,939 & -0.0235 & $9.76^{\star \star}$ & -0.0412 & $6.64^{\star \star}$ & -0.0567 & $4.46^{\star \star}$ \\
\hline FLAGSPC (Low) & 66,414 & -0.0150 & $7.56^{\star \star *}$ & -0.0332 & $6.97^{* *}$ & -0.0370 & $5.55^{\star \star}$ \\
\hline FLAGSPC (High) & 66,221 & -0.0275 & $12.81^{\star *}$ & -0.0382 & $8.03^{\star *}$ & -0.0327 & $5.16^{* \star}$ \\
\hline
\end{tabular}

RETRNK of -0.0214 , meaning that reporting lags are $2.14 \%$ greater per a 1 -standard-deviation drop in fund performance. Note that this increase goes beyond what one would predict based on the calendar month, the style category, and the fund's average reporting lag, due to the presence of fund fixed effects and interactions between style and month dummies. In model 7, we replace RETRNK with the change in the historical average return rank, $\triangle$ HIST_RETRNK, that would result from reporting the return in the current period. This drops the number of sample months in the regression from 60 to 59. The coefficient, -0.035 , again shows that reporting lags are longer for disclosures that adversely impact the fund's track record.

We interpret the negative relation between reporting lag and fund performance as evidence that fund managers strategically delay the reporting of poor performance. However, we also consider an alternative explanation in which a liquidity shock affecting a hedge fund investment strategy causes lower asset values (i.e., lower fund performance) and nonstrategic delays due to a lack of marketability of the assets traded within the strategy. In our analysis, we take several steps to address this alternative story. First, by including style and month interactions in our full-sample models (Panel A of Table 4), we control for a liquidity shock that would impact hedge funds in the same investment style and month. Second, our results are stable across investment styles and over time. Panel B of Table 4 reports that the coefficient on RETRNK in model 1 is negative and significant for 9 of 11 styles categories in style-by-style estimation with month fixed effects. Moreover, in the month-by-month estimation of model 6 (not tabulated), the coefficient on RETRNK is negative for 56 out of 59 months, and the average coefficient is $-3.65 \%$ ( $t$-statistic $=-9.79)$. We also do not find a significant 
correlation between our monthly estimates of the RETRNK coefficient and Pastor and Stambaugh's (2003) market liquidity factor (level of innovation). Thus, we conclude that a liquidity-based explanation cannot fully explain the propensity for bad news to be reported with a greater delay.

Models 2-7 in Table 4 omit fund fixed effects to shed light on fund characteristics that are associated with greater reporting lags. We find that reporting lags are greater among managers of funds with longer lockup and redemption-notice periods. Although, as discussed previously, this finding is consistent with longer reporting lags among managers with assets that are harder to value, it is also consistent with slower disclosure when the funds are less concerned about costs from delay because greater share restrictions make it more difficult for investors to redeem their shares. The remaining coefficients largely validate our univariate comparisons. Model 6 indicates a 13.8\% lower reporting lag among funds that have recently been audited, whereas the reporting lags of offshore funds are $11.6 \%$ greater than those of other funds.

Finally, the multivariate analysis reveals a strong positive correlation between reporting lags and suspicious patterns in returns. A 1-standard-deviation increase in the first principal component of the 11 individual data quality flags (FLAGSPC) is associated with a $1.41 \%$ increase in reporting lags. We also find some evidence in Panel B of Table 4 that the propensity for delaying poor performance is greater among funds with greater operational risk. The difference in the key Panel A coefficients between funds with above- and below-median FLAGSPC is negative in two of the three models (models 1 and 6) and significantly so in model 1 . Thus, we interpret this as further evidence that the disclosure of financial results is related to measures of operational risk and misreporting.

\section{B. Return Clusters}

The previous analysis shows that managers delay the release of poor performance. With a sufficiently long delay, say, a month or more, the manager can use the performance in subsequent months, if favorable, to help offset the negative information in prior months. In particular, because disclosure is both voluntary and irreversible, we might expect managers to withhold poor performance news in the hope that it is subsequently reversed. The advantage of withholding poor performance and disclosing it along with strong subsequent returns is that it could moderate the impact of investor redemptions and limit the impact on fund profitability and manager fees. In this section, we study such return clusters, defined as disclosures that contain at least two monthly return observations. ${ }^{19}$

From the final sample of 208,828 returns, we drop an additional 653 returns that were reported in clusters together with other returns from outside our final sample. The resulting sample contains either nonclusters or clusters that only contain returns from our sample period, thereby allowing us to fully characterize the earlier and latter halves of clusters. The final sample contains 9,202 clusters completed over our sample period, corresponding to 20,625 monthly returns or $10 \%$ of all sample returns.

\footnotetext{
${ }^{19}$ As noted previously, return clusters are not identifiable from the standard database because data vendors do not provide information on when managers report new information about fund returns.
} 
Table 5 summarizes the characteristics of style-adjusted returns for various subsamples of return clusters. Style-adjusted returns are fund returns minus the average return of all funds in the same style category and month. The first row shows that the earlier half of a cluster (First Half) has a negative average return $(-0.24 \%$ monthly), whereas the latter half (Second Half) has a positive average return $(0.21 \%$ monthly). The difference, $0.45 \%$, is significant. Although $80 \%$ of clusters contain exactly two returns, we find a similar reversal pattern among clusters that contain exactly three returns and also among the relatively few clusters that contain four or more returns. Overall, return clusters are associated with reversals of poor performance.

Table 5 also shows that the reversal pattern is mainly concentrated among younger, smaller funds. This suggests that the incentive to strategically delay the reporting of poor performance is greatest among less-established managers. This is understandable because, for these funds, poor performance is likely to have a greater impact on fund manager reputation and investor flows.

Next, we directly test for differences between clustered and nonclustered returns. Specifically, we run the following pooled regression model for the monthly returns in our sample:

$$
\mathrm{R}_{i t}=\alpha_{\mathrm{i}}+\gamma_{j t}+\beta_{1} \mathrm{FIRST} \_H A L F_{i t}+\beta_{2} \mathrm{SECOND \_ HALF}_{i t}+\epsilon_{i t},
$$

where $\mathrm{R}_{i t}$ is the monthly style-adjusted return on fund $i$ during month $t$, FIRST_HALF is an indicator variable that equals 1 if the return is part of the earlier half of a return cluster, and SECOND_HALF is an indicator variable that equals 1 if the return is part of the latter half of a return cluster. In equation (1)

\section{TABLE 5}

Style-Adjusted Returns Reported in Clusters

Table 5 presents summary statistics for the style-adjusted returns of 9,202 return clusters over Jan. 2009-Dec. 2013. A cluster is defined as at least two monthly returns reported on the same day. The style-adjusted return is the difference between the fund's raw return and the average return across all funds in the same month and style category. The table also reports the average of First Half and Second Half, which are defined as the average style-adjusted return over the earlier and latter halves, respectively, of each cluster, and a $t$-statistic from testing whether differences between the average return of the first and second halves of a cluster equal 0 . In the case of clusters with an odd number of returns, the middle return is classified as belonging to the earlier half of the cluster. Calculations use the returns reported to TASS on the RDATE. Results are reported for the full sample of clusters (All), by cluster size (i.e., the number of returns within the same cluster), and by AGE and AUM quintiles. ${ }^{*}$ and ${ }^{* *}$ denote significance at the $5 \%$ and $1 \%$ levels, respectively.

\begin{tabular}{|c|c|c|c|c|}
\hline Sample & $N$ & First Half & Second Half & $\underline{t \text {-Statistic }}$ \\
\hline All & 9,202 & -0.24 & 0.21 & $6.55^{\star \star}$ \\
\hline $\begin{array}{l}\text { Cluster Size } \\
\text { Size } 2 \\
\text { Size } 3 \\
\text { Size } \geq 4\end{array}$ & $\begin{array}{r}7,361 \\
1,518 \\
323\end{array}$ & $\begin{array}{l}-0.24 \\
-0.24 \\
-0.35\end{array}$ & $\begin{array}{l}0.21 \\
0.16 \\
0.29\end{array}$ & $\begin{array}{l}6.19^{\star \star} \\
2.49^{\star} \\
2.28^{\star}\end{array}$ \\
\hline $\begin{array}{l}\text { AGE Quintile } \\
\text { Q1 (youngest) } \\
\text { Q2 } \\
\text { Q3 } \\
\text { Q4 } \\
\text { Q5 (oldest) }\end{array}$ & $\begin{array}{l}1,739 \\
1,794 \\
1,676 \\
1,580 \\
1,439\end{array}$ & $\begin{array}{l}-0.53 \\
-0.42 \\
-0.22 \\
-0.15 \\
-0.01\end{array}$ & $\begin{array}{l}0.15 \\
0.15 \\
0.21 \\
0.00 \\
0.19\end{array}$ & $\begin{array}{l}4.15^{\star \star} \\
4.16^{\star \star} \\
3.08^{\star \star} \\
1.18 \\
1.46\end{array}$ \\
\hline $\begin{array}{l}\text { AUM Quintile } \\
\text { Q1 (smallest) } \\
\text { Q2 } \\
\text { Q3 } \\
\text { Q4 } \\
\text { Q5 (biggest) }\end{array}$ & $\begin{array}{r}992 \\
1,022 \\
1,026 \\
1,031 \\
1,139\end{array}$ & $\begin{array}{r}-0.47 \\
-0.31 \\
-0.44 \\
0.03 \\
-0.04\end{array}$ & $\begin{array}{r}0.36 \\
0.18 \\
-0.01 \\
0.09 \\
-0.07\end{array}$ & $\begin{array}{l}3.45^{\star \star} \\
2.26^{\star} \\
2.55^{\star} \\
0.38 \\
0.27\end{array}$ \\
\hline
\end{tabular}


we include interactions between style and month dummies $\left(\gamma_{j t}\right)$, and fund fixed effects $\left(\alpha_{i}\right)$ are also included in some specifications.

Table 6 shows that returns in the earlier half of return clusters correspond to significant below-average performance of $-0.31 \%$ monthly. In contrast, the latter half of a cluster corresponds to above-average performance $(0.17 \%$ monthly) and therefore represents a partial reversal of the lower returns generated during the earlier half. The difference in returns between the first and second halves of return clusters is significant at the $1 \%$ level. This difference goes beyond what we would expect based on the calendar month, style category, and each fund's average performance, due to the presence of fund fixed effects and interactions between style and month dummies.

Next, we consider a finer partition of returns. We interact FIRST_HALF and SECOND_HALF with an indicator variable that equals 1 if the fund's age is above the sample median (OLD). The results show that the difference between the first and second halves of a cluster is again most evident in the subsample of young funds (i.e., OLD $=0$ ). We also find similar patterns when we replace OLD with an indicator that equals 1 if the fund's AUM is above the sample median (BIG). Taken together, the results suggest that the propensity of reporting poor

\section{TABLE 6}

\section{Regressions of Style-Adjusted Returns on Cluster Variables}

The dependent variable is the fund's monthly style-adjusted return (the difference between the fund's raw return and the average return across all funds in the same month and style category). Independent variables include indicators for whether the return is part of the earlier (FIRST_HALF) or latter half (SECOND_HALF) of a cluster and indicators for whether the fund's age is above the sample median (OLD) and whether the fund's AUM is above the sample median (BIG). OLD and BIG are measured in the month prior to the return month. Calculations use the returns reported to TASS on the RDATE. Style and month interaction dummies are included in all models. Fund fixed effects are included in models 4-6. Standard errors account for heteroskedasticity and allow for clustering at either the month (models 1-3) or fund (models 4-6) level. The bottom panel reports $p$-values corresponding to $F$-tests on the coefficient estimates. * and ** indicate significance at the $5 \%$ and $1 \%$ levels, respectively.

\begin{tabular}{|c|c|c|c|c|c|c|}
\hline Variable & 1 & 2 & 3 & 4 & 5 & 6 \\
\hline (a) FIRST_HALF & $\begin{array}{l}-0.25 \\
3.98^{\star *}\end{array}$ & $\begin{array}{r}-0.38 \\
4.58^{* *}\end{array}$ & $\begin{array}{l}-0.41 \\
3.30^{\star \star}\end{array}$ & $\begin{array}{l}-0.31 \\
6.03^{* *}\end{array}$ & $\begin{array}{l}-0.36 \\
4.62^{\star \star}\end{array}$ & $\begin{array}{l}-0.48 \\
3.81^{\star \star}\end{array}$ \\
\hline (b) SECOND_HALF & $\begin{array}{l}0.21 \\
2.55^{\star}\end{array}$ & $\begin{array}{l}0.30 \\
2.56^{*}\end{array}$ & $\begin{array}{l}0.27 \\
1.82\end{array}$ & $\begin{array}{l}0.17 \\
2.87^{\text {** }}\end{array}$ & $\begin{array}{l}0.32 \\
3.66^{\star \star}\end{array}$ & $\begin{array}{l}0.22 \\
1.54\end{array}$ \\
\hline (c) FIRST_HALF $\times$ OLD & & $\begin{array}{l}0.24 \\
2.69^{* *}\end{array}$ & & & $\begin{array}{l}0.09 \\
0.90\end{array}$ & \\
\hline (d) SECOND_HALF $\times$ OLD & & $\begin{array}{r}-0.21 \\
1.47\end{array}$ & & & $\begin{array}{l}-0.33 \\
2.87^{\star \star}\end{array}$ & \\
\hline (e) FIRST_HALF $\times$ BIG & & & $\begin{array}{l}0.21 \\
1.65\end{array}$ & & & $\begin{array}{l}0.30 \\
2.15^{*}\end{array}$ \\
\hline (f) SECOND_HALF $\times$ BIG & & & $\begin{array}{r}-0.28 \\
1.77\end{array}$ & & & $\begin{array}{r}-0.19 \\
1.23\end{array}$ \\
\hline OLD & & $\begin{array}{l}0.10 \\
1.80\end{array}$ & & & $\begin{array}{l}0.10 \\
1.80\end{array}$ & \\
\hline$B I G$ & & & $\begin{array}{l}0.00 \\
0.09\end{array}$ & & & $\begin{array}{l}-0.54 \\
7.91^{\star \star}\end{array}$ \\
\hline Observations & 208,175 & 200,499 & 138,360 & 208,175 & 200,499 & 138,360 \\
\hline $\begin{array}{l}\text { Month } \times \text { style fixed effects } \\
\text { Fund fixed effects } \\
\text { Level of clustering }\end{array}$ & $\begin{array}{l}\text { Yes } \\
\text { No } \\
\text { Month }\end{array}$ & $\begin{array}{l}\text { Yes } \\
\text { No } \\
\text { Month }\end{array}$ & $\begin{array}{l}\text { Yes } \\
\text { No } \\
\text { Month }\end{array}$ & $\begin{array}{l}\text { Yes } \\
\text { Yes } \\
\text { Fund }\end{array}$ & $\begin{array}{l}\text { Yes } \\
\text { Yes } \\
\text { Fund }\end{array}$ & $\begin{array}{l}\text { Yes } \\
\text { Yes } \\
\text { Fund }\end{array}$ \\
\hline $\begin{array}{l}\text { F-Test: }(\mathrm{a})=(\mathrm{b}) \\
\text { F-Test: }(\mathrm{a})+(\mathrm{c})=(\mathrm{b})+(\mathrm{d}) \\
\text { F-Test: }(\mathrm{c})=(\mathrm{d}) \\
\text { F-Test: }(\mathrm{a})+(\mathrm{e})=(\mathrm{b})+(\mathrm{f}) \\
\text { F-Test: }(\mathrm{e})=(\mathrm{f})\end{array}$ & 0.0000 & $\begin{array}{l}0.0000 \\
0.0298 \\
0.0100\end{array}$ & $\begin{array}{l}0.0921 \\
0.0133\end{array}$ & 0.0000 & $\begin{array}{l}0.0000 \\
0.0032 \\
0.0029\end{array}$ & $\begin{array}{l}0.0228 \\
0.0130 \\
\end{array}$ \\
\hline
\end{tabular}


performance together with better subsequent performance in return clusters is greatest among managers of younger, smaller funds.

\section{Discussion of Cluster Results}

If monthly returns are independently and identically distributed, then the variance of the average return reported within a cluster will necessarily be lower than that of individual monthly returns. We note that the lower variance can be a partial gauge of the potential benefits from delaying the release of poor performance in the current period (denoted by $\mathrm{R}(1)<0$ ), especially when better performance is expected in the following period (denoted by $\mathrm{R}(2)>0$ ). To illustrate this, consider a situation in which the costs of liquidating assets and paying for fund outflows is roughly proportional to the (absolute) value of the strongly negative fund return. With our assumptions, dissipative costs would be proportional to $|R(1)|$ if the report is timely. On the other hand, if the performance report is delayed for a month and both returns are released together, the dissipative costs would be proportional to $|\min \{0, \mathrm{R}(1)+\mathrm{R}(2)\}|<|\mathrm{R}(1)|$. Hence, a rough indicator of the potential benefits of clustering is the extent to which clustering of $R(1)$ and $\mathrm{R}(2)$ reduces the volatility of monthly returns. The overall benefit would be affected by various other factors such as the investor-flow response to the delay in information release.

In our sample, the standard deviation of "cluster average returns" is $28 \%$ lower than the standard deviation of monthly returns reported individually (not tabulated). To put this into perspective, compare this reduction in variance with that achievable by existing models of performance smoothing. Getmansky et al. (2004) argue that illiquid asset exposure or deliberate smoothing can lead to distortions between reported and true economic returns, in which only a fraction of economic returns are reflected in contemporaneous reported returns. As a result, they show that the volatility of reported returns can be much lower than that true economic returns. The drop in volatility we observe from clustering would correspond to a smoothing strategy where $44 \%$ of the fund's true economic return is withheld from reported returns. The clustering strategy, however, achieves this result through delay rather than through distortions between reported and true economic returns. ${ }^{20}$

Our findings also reveal a potential delisting bias in studies of hedge fund performance. The patterns we find in return clusters suggest that managers are reluctant to disclose the results from prior months of poor performance unless they can be released along with results of better performance in more recent months. As a result, we are less likely to observe the returns of poorly performing funds that do not experience a reversal of performance. We investigate this further in the Internet Appendix by considering a simple clustering strategy in which a manager,

\footnotetext{
${ }^{20}$ To see this, note that Getmansky et al. (2004) express reported returns as $R_{t}^{o}=\sum_{k=0}^{K} \theta_{k} R_{t-k}^{*}$, where $R_{t}^{*}$ is the fund's true economic return in month $t$ and $\sum_{k=0}^{K} \theta_{k}=1$. This implies that the standard deviation of reported returns is then $\sigma \times\left(\sqrt{\theta_{0}^{2}+\theta_{1}^{2}+\cdots \theta_{k}^{2}}\right)$, where $\sigma$ is the standard deviation of true economic returns. Assuming $K=1$, a reduction in volatility of $28 \%$ corresponds to a smoothing coefficient $\theta_{0}$ satisfying $0.72=\sqrt{\theta_{0}^{2}+\left(1-\theta_{0}\right)^{2}}$, or $\theta_{0}=0.56$ as the positive root. This represents a smoothing parameter that is $1.38(=(0.92-0.56) / 0.26)$ standard deviations below the sample mean (Getmansky et al. (2004), Table 8).
} 
upon realizing that the fund return falls below a threshold, decides to delay the reporting of the return until the subsequent return is realized. If the sum of the two returns is above a (possibly different) threshold, then the manager reports both returns; otherwise, if the fund does not sufficiently reverse its earlier poor performance, then neither of the returns is reported. Our solution involves finding the two performance thresholds that are consistent with the evidence on reported clusters reported in Table 5. We find that the bias in the average reported returns that results from nonreporting is $2-4$ bps per month, that is, a product of a $-4 \%$ per month expected value of unreported returns times a $0.50 \%-1 \%$ frequency of unreported returns. This translates into an annualized bias of $24-48 \mathrm{bps}$, or $25 \%$ of the typical yearly fixed management fee (see Table 2 and the Internet Appendix).

\section{Predicting Fund Performance}

The evidence presented above shows that hedge fund managers delay the reporting of poor performance. In this section, we test whether reporting delays are associated with worse future performance and, therefore, whether information about a fund's disclosure policy carries investment value. Prior studies find that operational risk has explanatory power for fund performance, where operational risk is defined as the potential losses caused by a failure of operational, control, and accounting systems (see, e.g., Brown, Goetzmann, Liang, and Schwartz (2008), (2009), (2012)). These operational risks could also be reflective of an overall lower managerial ability. Hence, we might expect a negative relation between reporting lags and subsequent performance, to the extent that reporting lags are a symptom of operational risk and less-able management.

We first compare the returns on portfolios of hedge funds formed on the basis of historical reporting lags computed in "real time." Specifically, for each sample fund and quarter, we compute the average of all reporting lags corresponding to the available returns reported to TASS. For example, at the end of 2010Q1, historical reporting lags are based on all returns reported to TASS at the end of Mar. 2010. ${ }^{21}$ We then compute the fractional rank of each fund's average reporting lag across all funds in the same quarter and style category and sort funds into quintiles based on the fractional ranks. For the subsequent 3 months (2010Q2 in our example), we compute monthly portfolio returns as the equal-weighted average return across all funds in each quintile. Portfolios are then rebalanced each quarter based on the expanded sample of reporting lags. We winsorize the raw returns at the $1 \%$ and $99 \%$ levels and use the latest available returns as of the end of our collection period (Mar. 2014).

Table 7 presents the results. We uncover a strong negative relation between historical reporting lags and future hedge fund performance. The portfolio of the bottom quintile (i.e., fastest) of hedge funds delivers average style-adjusted returns of $0.05 \%$, whereas the top quintile (slowest) of hedge funds delivers $-0.11 \%$. The difference, $0.16 \%$ per month, is significant. The Fung and Hsieh (2004) benchmark delivers a larger abnormal return for the Q1-Q5 portfolio, a

\footnotetext{
${ }^{21}$ Note that because the Mar. 2010 return is not reported until Apr. 2010 at the earliest, it would not be included in the 2010Q1 average reporting lags for any fund. Conversely, because the median reporting lag is less than 1 month (Table 1), the 2010Q1 average reporting lag for many funds will include the reporting lag corresponding to Feb. 2010 performance.
} 
TABLE 7

Predicting Fund Performance in Real Time: Fast Versus Slow Portfolios

Table 7 summarizes the monthly performance of real-time portfolios tracking the reporting behavior of hedge fund managers. Hedge funds are sorted into portfolios based on historical average reporting lags. A fund's average reporting lag is computed using all available reporting lags at the end of the quarter. Averages are then ranked across all funds within the same style category. Equal-weighted monthly portfolio returns are then computed over the subsequent quarter based on fund quintile ranks. Portfolios are rebalanced every quarter based on the expanded set of reporting lags at the end of the prior quarter. Style-adjusted returns are computed as the fund's raw return minus the average return across all funds in the same month and style category. Fung and Hsieh (2004) alphas are obtained as the intercept from regressing the monthly portfolio returns (minus the one-month U.S. Treasury yield) on the following 7 factors: the Russell 2000 index return minus the S\&P 500 return (SP500t); the Citigroup Corporate BBB 10+ year index return minus the Fama treasury bond portfolio with maturities greater than 10 years (Bd10Yt); the excess returns (in excess of the risk-free rate) of SP500t and Bd10Yt; and Fung and Hsieh's (2001) bond, currency, and commodity trend-following factors. Raw returns are winsorized at the $1 \%$ and $99 \%$ levels and measured at the end of our data collection period (Mar. 2014). Results are reported for portfolios formed from the full sample of reporting lags (Panel A) and after excluding the reporting lags of returns that are reported in return clusters (Panel B). Each panel reports the average reporting lag for each quintile portfolio and also the performance results for various subsamples. Unrestricted funds have a lockup period of 0 and a redemption-notice period less than or equal to 30 days. Poor performers (Good performers) have an average return rank below (above) $50 \%$. Average return ranks are computed every quarter using the fund's available monthly returns. We first calculate the rank of each return across all funds in the same month and style category and then calculate the average return rank. * and ${ }^{* *}$ indicate significance at the $5 \%$ and $1 \%$ levels, respectively.

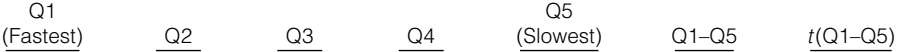

Panel A. Quintiles Based on All Reporting Lags

Average Reporting Lags

Unrestricted

4.81
5.26

12.00

11.61

11.96

16.93

17.37

23.75
23.06

23.64

Good performers

5.18

12.03

17.55

23.84

36.08
35.06

36.40

Style-Adjusted Returns

All funds

$0.05-0.01$

$-0.03$

$-0.09$

$-0.08$

$-0.02$

$-0.09$

$-0.20$

$-0.20$

Poor performers

-0.26
0.20

0.13

0.15

$-0.11$

$-0.12$

$-0.23$

0.02

\subsection{6}

$3.62^{* \star}$

-0.14
0.18

$-0.05$

Fung and Hsieh Alphas
All funds

\subsection{8}

0.17

Unrestricted

-0.05
-0.15

$-0.17$

0.05

0.05
-0.02

$-0.01$

0.05

0.12

$-0.07$

-0.07
-0.19

$-0.11$

$-0.02$

$\begin{array}{ll}0.15 & 2.24^{*} \\ 0.09 & 1.58 \\ 0.16 & 2.54^{\star} \\ & \\ 0.24 & 3.54^{\star \star} \\ 0.36 & 3.83^{\star \star} \\ 0.12 & 1.53 \\ 0.28 & 2.98^{\star \star}\end{array}$

Panel B. Quintiles Based on All Reporting Lags Except Clusters

\begin{tabular}{|c|c|c|c|c|c|c|c|}
\hline \multicolumn{8}{|c|}{ Average Reporting Lags } \\
\hline All funds & 4.85 & 10.43 & 14.84 & 19.53 & 28.20 & & \\
\hline Unrestricted & 4.50 & 10.17 & 14.38 & 18.86 & 27.73 & & \\
\hline Poor performers & 4.86 & 10.37 & 14.63 & 19.55 & 28.42 & & \\
\hline Good performers & 4.86 & 10.47 & 15.02 & 19.52 & 27.93 & & \\
\hline \multicolumn{8}{|c|}{ Style-Adjusted Returns } \\
\hline Unrestricted & 0.03 & -0.06 & -0.08 & -0.08 & $\begin{array}{l}-0.10 \\
-0.18\end{array}$ & $\begin{array}{l}0.20 \\
0.22\end{array}$ & $\begin{array}{l}4.14^{*} \\
3.52^{\text {** }}\end{array}$ \\
\hline Poor performers & -0.16 & -0.19 & -0.21 & -0.16 & -0.33 & 0.17 & $2.75^{\text {** }}$ \\
\hline Good performers & 0.18 & 0.22 & 0.13 & 0.13 & 0.00 & 0.18 & $2.84^{* *}$ \\
\hline \multicolumn{8}{|c|}{ Fung and Hsieh Alphas } \\
\hline All funds & 0.18 & -0.02 & 0.00 & 0.06 & -0.12 & 0.30 & $3.78^{* *}$ \\
\hline Unrestricted & 0.18 & -0.12 & -0.09 & -0.01 & -0.20 & 0.37 & $4.13^{* \star}$ \\
\hline Poor performers & 0.00 & -0.07 & -0.09 & 0.03 & -0.18 & 0.18 & 1.97 \\
\hline Good performers & 0.28 & 0.04 & 0.07 & 0.08 & -0.05 & 0.32 & $3.31^{* *}$ \\
\hline
\end{tabular}

significant $0.24 \%$ per month, or approximately $3 \%$ annualized. ${ }^{22}$ This provides further evidence that the return spreads we document are not explainable by

${ }^{22}$ The 7 factors are the Russell 2000 index return minus the S\&P 500 return (SP500t); the Citigroup Corporate BBB 10+ year index return minus the Fama treasury bond portfolio with maturities greater than 10 years $(\mathrm{Bd} 10 \mathrm{Yt}$ ); the excess returns (in excess of the risk-free rate) of SP500t and Bd10Yt; and Fung and Hsieh's (2001) bond, currency, and commodity trend-following factors.The trend-following factors can be found at http://faculty.fuqua.duke.edu/ dah7/DataLibrary/ TF-FAC.xls. 
differences in systematic risk exposure. We also find similar results for the subsample of funds that have a lockup period of 0 and a redemption-notice period of less than 30 days (Unrestricted). This suggests that our findings are of practical use for hedge fund investors because they are not concentrated among funds that impose severe restrictions on investor liquidity. Even so, as in other hedge fund studies, interpreting a long/short portfolio consisting of hedge funds requires more care because it is not possible to short sell a hedge fund. ${ }^{23}$ In this case, the spread return may best be interpreted as the return enhancement obtained by an investor who moves his or her capital from an untimely fund (Q5) to a timely one (Q1).

Prior studies find evidence that hedge fund performance is persistent (Jagannathan et al. (2010)). Therefore, our earlier finding that managers delay reporting of poor performance suggests that the predictability we document could be performance persistence because poorly performing funds will likely have longer historical reporting lags. We repeat our tests based on whether the fund has a historical return rank above (Good performers) or below (Poor performers) 50\%. Consistent with prior findings of performance persistence, we find that the returns are higher for all quintiles among the ex ante good performers. In addition, we again find a positive return spread between the Q1 and Q5 portfolios for each subsample. The coefficient is noticeably smaller for the subsample of poor performers, however.

As noted earlier, our evidence of return reversals within return clusters is consistent with poorly performing managers choosing to report to the database only after learning that their funds have recovered from a period of distress. The presence of return clusters could make it difficult to detect a negative relation between reporting delays and future performance, especially among the subsample of poor performers. This is because clusters will tend to feature poor returns that are reported with longer reporting lags (by construction, the earlier halves of return clusters have a reporting lag of at least 30 days) by managers who are no longer in financial distress. In other words, we do not observe the future performance of some managers who continue to experience financial distress because they have delayed and not yet resumed reporting to the database.

We explore this idea further in Panel B of Table 7. Here we again form portfolios based on average reporting lags, but we now exclude all reporting lags corresponding to returns reported in return clusters. We retain the forward-looking nature of our portfolio strategy because we look backward every quarter only at the available reporting lags (this time, ignoring return clusters) that are observable in TASS. If the clustering strategy is reflective of funds that are no longer in distress, then we should find stronger predictive power of reporting lags after excluding returns that are in a cluster. Panel B shows that this is indeed the case. The abnormal return spread is either $0.23 \%$ or $0.30 \%$ per month, depending on the benchmark. This is approximately $25 \%-45 \%$ greater than the return spread reported in Panel A using the full sample of reporting lags.

The refinement also delivers larger spreads for all of the fund subsamples, especially poor performers. Taken together, the results strongly show that the timeliness of reporting is predictive of fund performance and that the reversals of poor

\footnotetext{
${ }^{23}$ However, Sadka (2010) notes that a short position can be achievable given information about the fund's underlying positions.
} 
performance observed earlier for return clusters represent a relatively permanent resolution of delay-inducing distress. Last, Figure 3 shows that our finding of stronger relative performance among historically timely reporters is stable over time: the Q1-Q5 excess return spread is positive in 43 of the 57 months in our sample period. Overall, we interpret the evidence as consistent with the idea that operational risk, and its association with lower managerial ability, is an important predictor of fund performance. Apparently, the timeliness with which managers voluntarily report returns is a valuable input for hedge fund investor decision making.

\section{FIGURE 3}

Monthly Style-Adjusted Returns of Portfolios Tracking the Historical Timeliness of Hedge Fund Return Reporting

Average reporting lags are calculated every quarter for each fund in our sample using all available observations through the end of the quarter. Average reporting lags are then ranked across all funds in the same style category and quarter. The Q1-Q5 spread is the difference in monthly style-adjusted returns, over the subsequent quarter, between equal-weighted portfolios of funds in the lowest (Q1) and highest (Q5) average reporting lag quintiles. Style-adjusted returns are raw returns minus the average return of funds in the same style category, using the latest available returns reported to TASS at the end of our collection period (Mar. 2014). Raw returns are winsorized at the $1 \%$ and $99 \%$ levels. Results are reported using the full sample of reporting lags (solid line) and after excluding the reporting lags of returns that are reported in clusters (dashed line).

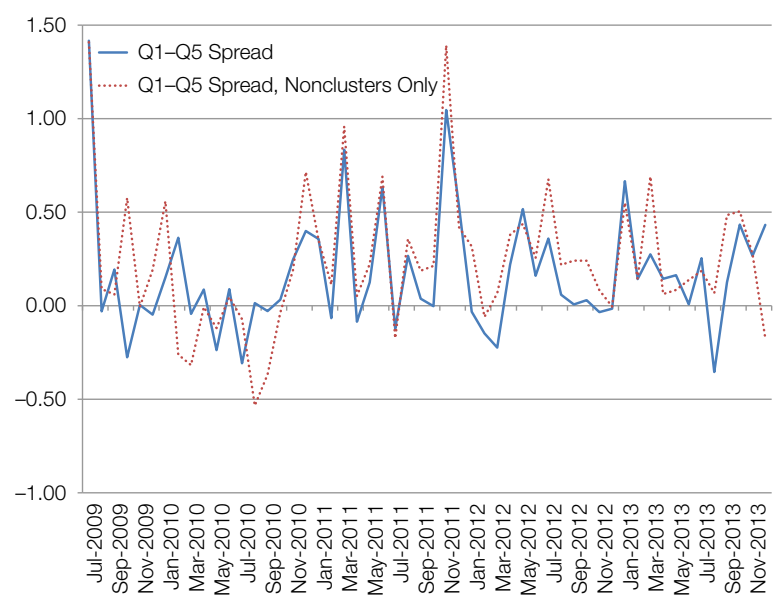

\section{E. Monthly Cross-Sectional Regressions}

Next, we estimate month-by-month cross-sectional regressions of hedge fund performance in the spirit of Fama and MacBeth (1973). This allows us to further isolate the predictive power of reporting lags from other known predictors of hedge fund performance. We estimate the following regression model of monthly hedge fund returns:

(2) RETURN $_{i}=a+b \times$ HIST $\operatorname{REPLAG}_{i}+\sum_{j=1}^{k} \gamma_{j} \times \mathrm{CONTROL}_{i, j}+\epsilon_{i}$,

where HIST_REPLAG ${ }_{i}$ is defined as the within-style fractional rank of fund $i$ 's historical average reporting lag. As control variables in equation (2), we 
include style dummies; historical average return rank (HIST_PERF); HWM; 1 plus the natural logarithms of AGE, INC_FEE, MGMT_FEE, and NOTICE; and dummy variables for whether the fund has a lockup period (D_LOCKUP) and reports AUM to the database (D_AUM). We measure HIST_REPLAG, HIST_PERF, AGE, and AUM at the end of the prior quarter. All independent variables (except dummies) are standardized to have a 0 mean and unit variance.

Table 8 presents the averages of the monthly coefficients for various models. The results again show that historical reporting lags predict fund returns. For example, from model 1, we predict that a 1-standard-deviation increase in HIST_REPLAG is associated with fund returns that are approximately $-0.035 \%$ lower per month. The relation between future performance and reporting lags is more negative, $-0.048 \%$ per month, after excluding clusters from the calculation of HIST_REPLAG. Our findings for the other variables are generally consistent with prior studies. In particular, we find that fund performance is positively

TABLE 8

Predicting Hedge Fund Performance: Reporting Lags and Other Fund Characteristics

Table 8 reports the results from month-by-month regressions of hedge fund returns on historical reporting lags and other fund characteristics. The dependent variable is the monthly fund return. HIST_REPLAG is the rank of the average reporting lag and is computed for each fund using all available reporting lags at the end of the prior quarter. Averages are then ranked across all funds within the same style category. HIST_PERF is the fund's average return rank based on all returns reported to TASS at the end of the prior quarter. Return ranks are computed relative to all returns in the same month and style category. Other independent variables include style category dummies and a dummy variable that equals 1 if the lockup period is greater than 0 (D_LOCKUP). All other variables are defined in Tables 1-4. AGE and AUM are measured at the end of the prior quarter. The table reports the average of the coefficient estimates (and corresponding $t$-statistics) calculated over the 57 months across 2009Q2-2013Q4. Results are reported when HIST_REPLAG is computed from the full sample of available reporting lags (models 1-2), the subsample of available reporting lags after excluding those corresponding to return clusters (models 3-4), and after further excluding restricted funds (models 5-6). Unrestricted funds have a lockup period of 0 and a redemption-notice period less than or equal to 30 days. Raw returns are winsorized at the $1 \%$ and $99 \%$ levels and measured at the end of our data collection period (Mar. 2014). ${ }^{*}$ and ${ }^{* \star}$ indicate significance at the $5 \%$ and $1 \%$ levels, respectively.

\begin{tabular}{|c|c|c|}
\hline HIST_REPLAG & $\begin{array}{l}-0.035 \\
-2.27^{\star}\end{array}$ & $\begin{array}{l}-0.039 \\
-2.52^{*}\end{array}$ \\
\hline $\ln (1+$ INC_FEE $)$ & & $\begin{array}{l}0.013 \\
0.46\end{array}$ \\
\hline In(1+MGMT_FEE) & & $\begin{array}{l}-0.042 \\
-2.65^{*}\end{array}$ \\
\hline HWM & & $\begin{array}{l}-0.025 \\
-0.66\end{array}$ \\
\hline D_LOCKUP & & $\begin{array}{l}0.070 \\
1.39\end{array}$ \\
\hline $\ln (1+$ NOTICE $)$ & & $\begin{array}{l}0.059 \\
1.88\end{array}$ \\
\hline $\ln (1+A G E)$ & & $\begin{array}{l}0.066 \\
2.29^{*}\end{array}$ \\
\hline HIST_PERF & & $\begin{array}{l}0.242 \\
4.29^{\text {** }}\end{array}$ \\
\hline D_AUM & & $\begin{array}{l}0.091 \\
2.52^{*}\end{array}$ \\
\hline D_AUM $\times \ln (1+\mathrm{AUM})$ & & $\begin{array}{l}-0.029 \\
-1.19\end{array}$ \\
\hline Style dummies & Yes & Yes \\
\hline Observations & 57 & 57 \\
\hline
\end{tabular}

\begin{tabular}{|c|c|c|c|}
\hline \multicolumn{2}{|c|}{ Ex-Clusters } & \multicolumn{2}{|c|}{$\begin{array}{l}\text { Ex-Clusters, } \\
\text { Unrestricted }\end{array}$} \\
\hline 3 & 4 & 5 & 6 \\
\hline \multirow[t]{10}{*}{$\begin{array}{l}-0.048 \\
-2.93^{\star \star}\end{array}$} & $\begin{array}{l}-0.051 \\
-3.01^{* *}\end{array}$ & $\begin{array}{l}-0.049 \\
-2.65^{*}\end{array}$ & $\begin{array}{l}-0.031 \\
-1.61\end{array}$ \\
\hline & $\begin{array}{l}0.012 \\
0.45\end{array}$ & & $\begin{array}{l}0.028 \\
0.80\end{array}$ \\
\hline & $\begin{array}{l}-0.041 \\
-2.56^{*}\end{array}$ & & $\begin{array}{l}-0.026 \\
-1.50\end{array}$ \\
\hline & $\begin{array}{l}-0.018 \\
-0.48\end{array}$ & & $\begin{array}{l}-0.088 \\
-1.78\end{array}$ \\
\hline & $\begin{array}{l}0.076 \\
1.49\end{array}$ & & \\
\hline & $\begin{array}{l}0.062 \\
1.92\end{array}$ & & $\begin{array}{l}0.034 \\
0.96\end{array}$ \\
\hline & $\begin{array}{l}0.065 \\
2.27^{*}\end{array}$ & & $\begin{array}{l}0.080 \\
2.50^{*}\end{array}$ \\
\hline & $\begin{array}{l}0.246 \\
4.28^{* *}\end{array}$ & & $\begin{array}{l}0.197 \\
3.27^{* \star}\end{array}$ \\
\hline & $\begin{array}{l}0.089 \\
2.40^{*}\end{array}$ & & $\begin{array}{l}0.084 \\
1.91\end{array}$ \\
\hline & $\begin{array}{l}-0.028 \\
-1.13\end{array}$ & & $\begin{array}{l}-0.009 \\
-0.35\end{array}$ \\
\hline Yes & Yes & Yes & Yes \\
\hline 57 & 57 & 57 & 57 \\
\hline
\end{tabular}


related to share restrictions (Aragon (2007)) and past performance (Boyson (2008), Jagannathan et al. (2010)). Overall, the evidence confirms our earlier analysis of portfolio returns and shows that the predictability we document is separate from other known predictors of fund performance.

As noted previously, the decision to delay reporting may be related to the difficulty in correctly valuing illiquid assets. One concern may therefore be that the relation between past reporting lags and future returns is driven by differences in the fund's exposure to illiquid assets and that these differences are not fully accounted for by our use of style-adjusted returns or Fung and Hsieh (2004) alphas as performance benchmarks. To further address this issue, we make two modifications to the return regression equation. First, we include an additional control variable (RESTATE_DIFF) that represents the difference between the most recently reported return (i.e., the dependent variable) and the RDATE return as a proxy for how illiquid and difficult to value the fund's assets are. Second, we replace the fund's historical reporting lag with FAM_REPLAG, the average HIST_REPLAG across other funds in the same family (excluding the fund of interest). If delay does capture operational risk, then we would expect a similar negative relation between fund performance and the delay for all other funds run by the same manager.

Table 9 shows that the relation between family delay and fund performance is indeed negative and significant. We find the same result even after we refine our family variable to include only those family funds with a return correlation of less than $75 \%$ with the fund of interest (DIST_FAM_REPLAG). This relation withstands the inclusion of our asset illiquidity proxy, RESTATE_DIFF or its

\section{TABLE 9}

Predicting Hedge Fund Performance:

Family Reporting Lags and Return Restatements

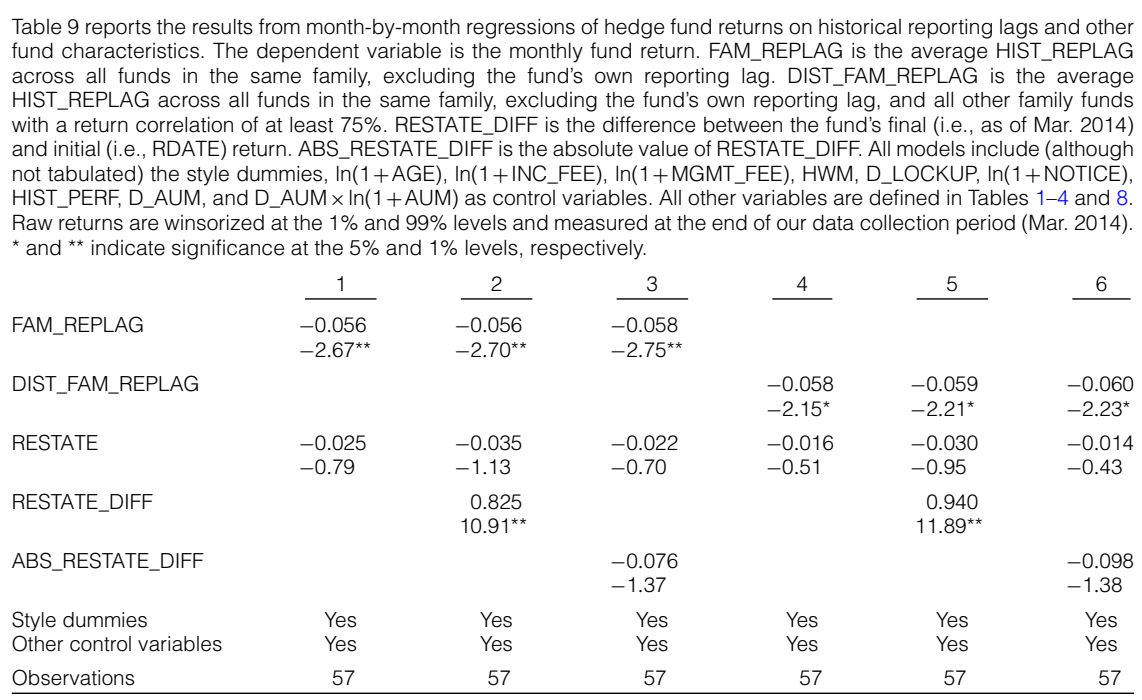


absolute value, in all specifications. ${ }^{24}$ Overall, the predictability of reporting lags is unlikely to be explained by differences in illiquid asset exposure across slowand fast-reporting funds. Instead, a fund's timeliness of reporting to a public database is a symptom of the broader operational risk of the fund manager that is informative about future performance.

\section{F. Monthly Fund Investor Flows}

The previous analysis shows that managers delay reporting of poor performance. This behavior can benefit fund managers to the extent that delays reduce the flow response of investors to past performance. On the other hand, reporting delays may convey a negative signal to fund investors, thereby decreasing capital flows. To test these predictions, we estimate a pooled regression of monthly net investor flows on past performance over 2009-2013. Specifically,

$$
\begin{aligned}
\text { FLOW }_{i, m}= & \alpha_{i}+\beta \mathrm{PERF}_{i, m-1}+\theta \mathrm{DELAY}_{i, m-1} \\
& +\gamma \mathrm{PERF}_{i, m-1} \times \operatorname{DELAY}_{i, m-1}+\mathrm{CONTROLS}+\epsilon_{i, m},
\end{aligned}
$$

where $\mathrm{FLOW}_{i, m}=\left(\mathrm{AUM}_{i, m}-\mathrm{AUM}_{i, m-1} \times\left(1+\mathrm{RETURN}_{i, m}\right)\right) / \mathrm{AUM}_{i, m-1}, \mathrm{AUM}_{i, m}$ denotes fund $i$ 's assets under management at the end of month $m$, and $\operatorname{RETURN}_{i, m}$ denotes fund $i$ 's latest available return during month $m$ as of the end of our collection period (Mar. 2014). ${ }^{25}$

The key independent variables in the flow regression equation (equation (3)) are PERF, DELAY, and the interaction of these two variables. We measure PERF using the 3-month rolling average of RETRNK, the fractional rank of the fund's return relative to all other funds in same month and style category. A finding of $\beta>0$ would indicate that investor flows respond favorably to better fund performance in prior months. DELAY is the natural logarithm of the 3-month rolling average of the fund's reporting lag. Therefore, $\theta$ measures the marginal effect of a lack of timeliness on investor flows in the subsequent month. A finding of $\theta<0$ would indicate that a greater reporting delay is interpreted as a negative signal by investors, and therefore that delay entails a cost to fund managers. ${ }^{26}$ The interaction $(\mathrm{PERF} \times \mathrm{DELAY}$ ) measures the marginal effect of reporting delays on the flow-performance sensitivity. A finding of $\gamma<0$ would signify that investors respond much less to performance when performance information is disclosed in a less timely fashion, and therefore that delaying poor performance entails a benefit to fund managers. Last, as control variables, we include fund and month fixed effects and also the natural logarithm of AGE and AUM.

Table 10 reveals that monthly net flows respond positively to past performance. For example, model 2 shows that a 1-standard-deviation increase in PERF

\footnotetext{
${ }^{24}$ The positive and significant coefficient on RESTATE_DIFF is expected, given that it is the difference between our dependent variable and the RDATE return.

${ }^{25}$ To compute flows, we require $\mathrm{AUM}_{i m}$ and $\mathrm{AUM}_{i, m-1}$ to be contiguous. However, a few observations in our flow regressions have a missing value of PERF for at least 1 of the 3 contiguous months immediately preceding the flow month $(\mathrm{m})$. In these cases, we use the three most recent nonmissing values of PERF.

${ }^{26}$ We use 3-month rolling averages of returns and reporting lags because a fund manager's longerterm pattern of performance and reporting behavior, in addition to whether the fund has delayed the reporting of its most recent monthly return, may factor into an investor's decision to invest with the fund.
} 
TABLE 10

Monthly Net Fund Flows and TASS Reporting Delays

\begin{tabular}{|c|c|c|c|c|c|c|}
\hline & \multicolumn{2}{|c|}{ All } & \multicolumn{2}{|c|}{ Unrestricted } & \multicolumn{2}{|c|}{ Restricted } \\
\hline & 1 & 2 & 3 & 4 & 5 & 6 \\
\hline PERF & $\begin{array}{r}0.0064 \\
17.13^{\star \star}\end{array}$ & $\begin{array}{c}0.0062 \\
16.89^{\star \star}\end{array}$ & $\begin{array}{r}0.0081 \\
16.10^{* \star}\end{array}$ & $\begin{array}{c}0.0069 \\
14.00^{* *}\end{array}$ & $\begin{array}{l}0.0033 \\
6.49^{\star \star}\end{array}$ & $\begin{array}{l}0.0037 \\
6.57^{\star *}\end{array}$ \\
\hline DELAY & & $\begin{array}{c}-0.0035 \\
4.72^{\star \star}\end{array}$ & & $\begin{array}{c}-0.0058 \\
5.78^{\star *}\end{array}$ & & $\begin{array}{l}0.0020 \\
1.84\end{array}$ \\
\hline PERF $\times$ DELAY & & $\begin{array}{c}-0.0036 \\
8.97^{\star \star}\end{array}$ & & $\begin{array}{c}-0.0035 \\
7.00^{* *}\end{array}$ & & $\begin{array}{c}-0.0009 \\
1.26\end{array}$ \\
\hline $\ln (1+A G E)$ & $\begin{array}{c}-0.0346 \\
11.20^{\star \star}\end{array}$ & $\begin{array}{c}-0.0339 \\
11.01^{\star \star}\end{array}$ & $\begin{array}{c}-0.0382 \\
9.33^{\star \star}\end{array}$ & $\begin{array}{c}-0.0374 \\
9.16^{\star \star}\end{array}$ & $\begin{array}{c}-0.0252 \\
5.73^{\star \star}\end{array}$ & $\begin{array}{c}-0.0255 \\
5.78^{\star \star}\end{array}$ \\
\hline $\ln (1+A \cup M)$ & $\begin{array}{c}-0.0214 \\
11.54^{\star \star}\end{array}$ & $\begin{array}{c}-0.0216 \\
11.67^{\star \star}\end{array}$ & $\begin{array}{c}-0.0258 \\
10.20^{\star *}\end{array}$ & $\begin{array}{c}-0.0261 \\
10.32^{\star \star}\end{array}$ & $\begin{array}{c}-0.0152 \\
5.89^{* *}\end{array}$ & $\begin{array}{r}-0.0150 \\
5.83^{\star \star}\end{array}$ \\
\hline $\begin{array}{l}\text { Observations } \\
R^{2}\end{array}$ & $\begin{array}{c}122,525 \\
0.09\end{array}$ & $\begin{array}{c}122,525 \\
0.09\end{array}$ & $\begin{array}{c}80,319 \\
0.16\end{array}$ & $\begin{array}{c}80,319 \\
0.16\end{array}$ & $\begin{array}{c}42,206 \\
0.02\end{array}$ & $\begin{array}{c}42,206 \\
0.02\end{array}$ \\
\hline $\begin{array}{l}\text { Fund dummies } \\
\text { Month dummies } \\
\text { Level of clustering }\end{array}$ & $\begin{array}{l}\text { Yes } \\
\text { Yes } \\
\text { Fund }\end{array}$ & $\begin{array}{l}\text { Yes } \\
\text { Yes } \\
\text { Fund }\end{array}$ & $\begin{array}{l}\text { Yes } \\
\text { Yes } \\
\text { Fund }\end{array}$ & $\begin{array}{l}\text { Yes } \\
\text { Yes } \\
\text { Fund }\end{array}$ & $\begin{array}{l}\text { Yes } \\
\text { Yes } \\
\text { Fund }\end{array}$ & $\begin{array}{l}\text { Yes } \\
\text { Yes } \\
\text { Fund }\end{array}$ \\
\hline
\end{tabular}

is associated with an increase in net flows of $0.62 \%$ over the subsequent month, above and beyond what one would expect for the same fund and calendar month. A positive flow-performance relation supports the notion that investors move their capital away from poorly performing funds, giving managers with poor returns the incentive to delay the release of this information. Consistent with delay providing a benefit to fund managers, model 2 shows that the coefficients on the interaction term $($ PERF $\times$ DELAY) is indeed negative and significant. To understand the economic magnitude of these effects, note that $-0.62 \%$ is the expected impact on current monthly flows of a 1-standard-deviation drop in average performance over the prior 3 months for a fund with an average reporting lag (i.e., DELAY $=0$ ). If, instead, the fund's average reporting lag were 1 standard deviation above the average, then the expected impact on net flows would be only $-0.26 \%$.

\section{G. Discussion of Flow Results}

The coefficient on DELAY represents the cost to managers (in terms of flows) from delay. We expect a negative coefficient because investors will rationally attribute greater delays to poor performance. Consistent with a negative signal from nondisclosure, the coefficient on DELAY is negative (model 2: $-0.35 \%$, $t$-statistic $=4.72$ ). We can infer the threshold level of performance below which managers choose to delay. Suppose a manager has a 3-month-rolling-average reporting lag of 1 standard deviation above the average. This entails a cost of $-0.35 \%$ during the subsequent month. On the other hand, the reduction in flow response over the same period to the performance of the previous 3 months is $0.36 \%$ per 1 -standard-deviation drop in performance. Therefore, such a delay is 
justified for a manager with a performance less than or equal to 1 standard deviation below the mean.

Studies of hedge fund flows are complicated by share restrictions, such as like lockups and notice periods, that outright restrict the ability of investors to redeem shares. For example, Ding et al. (2009) show that share restrictions can have a significant effect on the flow-performance relation of individual hedge funds. This is relevant here because we would expect the costs from delay to be strongest when investors in the fund can quickly redeem fund shares. Therefore, in Table 10 we report results separately for the subsample of unrestricted (Panel B) and restricted (Panel C) funds. As expected, when we repeat our flow regression for the subsample of restricted funds (i.e., funds with a lockup period or a redemption notice-period longer than 30 days), we find that the coefficients on PERF, DELAY, and PERF $\times$ DELAY are smaller and less significant. In contrast, for unrestricted funds, the coefficient on DELAY is larger in magnitude, indicating a greater cost from nondisclosure for this subsample. This implies a much lower threshold level of performance (1.66 standard deviations below the mean) for unrestricted funds to realize a net benefit from delays in reporting performance.

Finally, our evidence shows that a lack of timely reporting is associated with lower subsequent net flows. As noted previously, however, we cannot identify the extent to which this is driven by greater outflows of existing investors or fewer inflows from outside potential investors. For example, it is plausible that existing investors in some funds receive their information in a timely fashion through other channels (say, directly from the manager) even though the manager is delaying the reporting of returns to a public database. However, our finding that greater public reporting delays predicts worse fund performance suggests that existing investors have an incentive to monitor the manager's public reporting behavior, even if the manager is reporting to existing investors in a timely fashion.

\section{H. Main Results for Funds of Funds}

In this section, we repeat our main analysis for the (heretofore excluded) holdout sample of 5,225 FoFs. Fung and Hsieh (2000) argue that the investment returns of FoFs contain fewer measurement biases than those of individual hedge funds (see also Fung et al. (2008)). The idea is that the investment experience of disappearing funds will be reflected in the returns of FoFs, which, presumably, are themselves less likely to have stopped reporting to TASS. In other words, the investment experience of actual hedge fund investors (i.e., FoFs) provides a more reliable picture of the investment experience of hedge funds.

This issue is particularly relevant in the current setting. One concern with using reporting lags to predict fund performance is that funds with greater reporting delays are more likely to stop reporting to the database. In our sample, $45 \%$ of funds in the bottom quintile of historical reporting lags (i.e., fastest reporters) become defunct over our sample period. In comparison, $69 \%$ of the top quintile of historical reporting lags (i.e., slowest reporters) become defunct. This will make it difficult to detect a negative relation between reporting lags and future performance, to the extent that the returns of defunct funds are lower than average.

To address this issue, we repeat our main analysis for the subsample of FoFs. The results are reported in Table 11. First, in Panel A, we repeat our analysis of 
return clusters. We again find that the first half of clusters is associated belowaverage fund performance. However, in contrast to our earlier findings, we find weaker evidence of a reversal between the first and second halves of return clusters. This helps validate our use of FoFs as a "cleaner" sample to test whether reporting lags can predict future hedge fund performance.

TABLE 11

Main Results for Key Holdout Sample: FoFs

Table 11 reports the results from repeating our main tests on the sample of 5,225 hedge funds in the FoF style category (excluded from the main analysis). ${ }^{*}$ and ${ }^{* *}$ indicate significance at the $5 \%$ and $1 \%$ levels, respectively.

Panel A. Repeat Table 6 for FoFs

(a) FIRST_HALF

(b) SECOND_HALF

(c) FIRST_HALF $\times$ OLD

(d) SECOND_HALF $\times$ OLD

(e) FIRST_HALF $\times$ BIG

(f) SECOND_HALF $\times$ BIG

OLD

BIG

Observations

Month fixed effects

Fund fixed effects

Level of clustering

F-Test: $(a)=(b)$

F-Test: $(\mathrm{a})+(\mathrm{c})=(\mathrm{b})+(\mathrm{d})$

F-Test: $(\mathrm{c})=(\mathrm{d})$

F-Test: $(\mathrm{a})+(\mathrm{e})=(\mathrm{b})+(\mathrm{f})$

F-Test: $(\mathrm{e})=(\mathrm{f})$

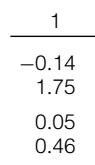

\begin{tabular}{c}
2 \\
\hline-0.29 \\
$2.21^{\star}$ \\
-0.11 \\
0.78 \\
0.30 \\
1.98 \\
0.36 \\
$2.08^{\star}$
\end{tabular}

0.06

1.92

Panel B. Repeat Table 7 for FoFs

\begin{tabular}{lrr}
\hline & $\begin{array}{c}\text { Q1 } \\
\text { (Fastest) }\end{array}$ & Q2 \\
\cline { 2 - 3 } Style-Adjusted Returns & & \\
All funds & 0.08 & \\
Unrestricted & 0.06 & -0.01 \\
Poor performers & -0.18 & -0.05 \\
Good performers & 0.24 & 0.13 \\
Style-Adjusted Returns, Exclude Clusters \\
All funds & 0.09 & 0.04 \\
Unrestricted & 0.08 & -0.06 \\
Poor performers & -0.16 & -0.11 \\
Good performers & 0.23 & 0.16 \\
Fung and Hsieh Alphas & \multicolumn{2}{c}{} \\
All funds & 0.04 & -0.06 \\
Unrestricted & 0.05 & -0.11 \\
Poor performers & -0.25 & -0.13 \\
Good performers & 0.21 & 0.00 \\
Fung and Hsieh Alphas, Exclude Clusters \\
All funds & 0.07 & -0.11 \\
Unrestricted & 0.09 & -0.20 \\
Poor performers & -0.20 & -0.25 \\
Good performers & 0.21 & 0.00
\end{tabular}

Q4

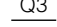

0.05

$-0.02$

$-0.09$

0.13

0.09

0.04

$-0.02$

0.15

$-0.05$

-0.05
-0.11

$-0.17$

0.01

$-0.01$

$-0.04$

$-0.07$

0.03

$-0.19$

$-0.25$

$-0.40$

0.02

$-0.12$

$-0.16$

$-0.25$

0.00

$-0.23$

-0.23
-0.26

$-0.39$

$-0.05$

$-0.19$

$-0.21$

$-0.28$

$-0.09$

\begin{tabular}{c}
3 \\
\hline-0.38 \\
$2.33^{\star}$ \\
-0.24 \\
0.87 \\
\end{tabular}

0.32

$2.21^{*}$

0.45

1.87
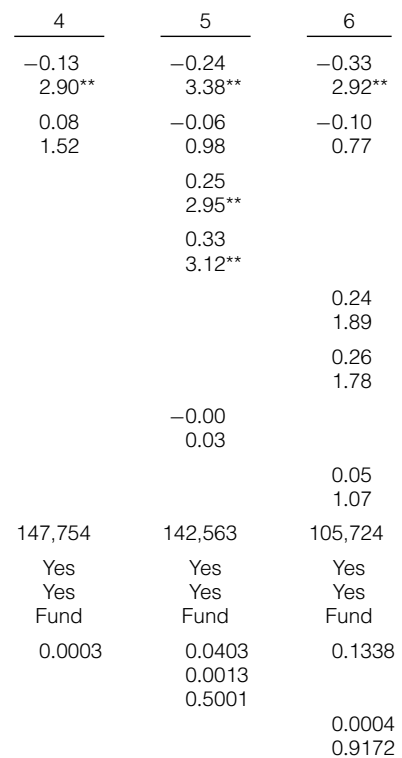

0.24

1.89

0.26

1.78

$-0.00$

0.03

0.14

$3.53^{\text {** }}$

105,724

Yes

No

Month

0.6240

0.0064

0.6555

$\begin{array}{cc} & 0.05 \\ & 1.07 \\ 142,563 & 105,724 \\ \text { Yes } & \text { Yes } \\ \text { Yes } & \text { Yes } \\ \text { Fund } & \text { Fund } \\ 0.0403 & 0.1338 \\ 0.0013 & \\ 0.5001 & \\ & 0.0004 \\ & 0.9172\end{array}$

Q5

\begin{tabular}{c} 
(Slowest) \\
\hline \\
-0.24 \\
-0.38 \\
-0.50 \\
0.14 \\
\\
-0.34 \\
-0.42 \\
-0.66 \\
0.10 \\
\\
-0.27 \\
-0.40 \\
-0.49 \\
0.05 \\
\\
-0.35 \\
-0.42 \\
-0.64 \\
0.07
\end{tabular}

Q1-Q5

t(Q1-Q5) 
TABLE 11 (continued)

Main Results for Key Holdout Sample: FoFs

Panel C. Repeat Table 8 for FoFs

\begin{tabular}{|c|c|c|c|c|c|c|}
\hline & \multicolumn{2}{|c|}{ All } & \multicolumn{2}{|c|}{ Ex-Clusters } & \multicolumn{2}{|c|}{$\begin{array}{l}\text { Ex-Clusters, } \\
\text { Unrestricted }\end{array}$} \\
\hline & 1 & 2 & 3 & 4 & 5 & 6 \\
\hline HIST_REPLAG & $\begin{array}{l}-0.078 \\
-3.83^{* *}\end{array}$ & $\begin{array}{l}-0.066 \\
-3.37^{* *}\end{array}$ & $\begin{array}{l}-0.086 \\
-4.02^{\star \star}\end{array}$ & $\begin{array}{l}-0.070 \\
-3.42^{* \star}\end{array}$ & $\begin{array}{l}-0.093 \\
-3.37^{* *}\end{array}$ & $\begin{array}{l}-0.069 \\
-2.69^{\star \star}\end{array}$ \\
\hline $\ln \left(1+\operatorname{INC} \_F E E\right)$ & & $\begin{array}{l}0.002 \\
0.07\end{array}$ & & $\begin{array}{l}0.002 \\
0.09\end{array}$ & & $\begin{array}{l}-0.002 \\
-0.06\end{array}$ \\
\hline $\ln (1+$ MGMT_FEE) & & $\begin{array}{l}0.010 \\
0.64\end{array}$ & & $\begin{array}{l}0.010 \\
0.63\end{array}$ & & $\begin{array}{l}0.024 \\
1.28\end{array}$ \\
\hline HWM & & $\begin{array}{l}-0.071 \\
-1.73\end{array}$ & & $\begin{array}{l}-0.071 \\
-1.74\end{array}$ & & $\begin{array}{l}-0.120 \\
-1.52\end{array}$ \\
\hline D_LOCKUP & & $\begin{array}{l}0.159 \\
5.38^{\star \star}\end{array}$ & & $\begin{array}{l}0.150 \\
4.89^{* *}\end{array}$ & & \\
\hline $\ln (1+$ NOTICE $)$ & & $\begin{array}{l}0.031 \\
1.74\end{array}$ & & $\begin{array}{l}0.030 \\
1.66\end{array}$ & & $\begin{array}{l}0.001 \\
0.02\end{array}$ \\
\hline $\ln (1+A G E)$ & & $\begin{array}{l}0.014 \\
1.11\end{array}$ & & $\begin{array}{l}0.014 \\
1.11\end{array}$ & & $\begin{array}{l}0.020 \\
1.22\end{array}$ \\
\hline HIST_PERF & & $\begin{array}{l}0.220 \\
7.01^{\star *}\end{array}$ & & $\begin{array}{l}0.221 \\
7.01^{\text {** }}\end{array}$ & & $\begin{array}{l}0.220 \\
6.46^{\star \star}\end{array}$ \\
\hline D_AUM & & $\begin{array}{l}0.014 \\
0.49\end{array}$ & & $\begin{array}{l}0.014 \\
0.52\end{array}$ & & $\begin{array}{l}-0.028 \\
-0.67\end{array}$ \\
\hline D_AUM $\times \ln (1+A \cup M)$ & & $\begin{array}{l}0.062 \\
3.62^{\star \star}\end{array}$ & & $\begin{array}{l}0.061 \\
3.54^{\star \star}\end{array}$ & & $\begin{array}{l}0.072 \\
3.27^{\star \star}\end{array}$ \\
\hline Observations & 57 & 57 & 57 & 57 & 57 & 57 \\
\hline \multicolumn{7}{|c|}{ Panel D. Repeat Table 9 for FoFs } \\
\hline & 1 & 2 & 3 & 4 & 5 & 6 \\
\hline FAM_REPLAG & $\begin{array}{l}-0.056 \\
-3.19^{* \star}\end{array}$ & $\begin{array}{l}-0.051 \\
-2.75^{\star \star}\end{array}$ & $\begin{array}{l}-0.056 \\
-3.15^{\star \star}\end{array}$ & & & \\
\hline DIST_FAM_REPLAG & & & & $\begin{array}{l}-0.060 \\
-3.31^{\star \star}\end{array}$ & $\begin{array}{l}-0.054 \\
-3.02^{\star \star}\end{array}$ & $\begin{array}{l}-0.059 \\
-3.36^{\star \star}\end{array}$ \\
\hline RESTATE & $\begin{array}{l}-0.065 \\
-2.89^{* *}\end{array}$ & $\begin{array}{l}-0.057 \\
-2.51^{*}\end{array}$ & $\begin{array}{l}-0.054 \\
-2.40^{\star}\end{array}$ & $\begin{array}{l}-0.091 \\
-3.16^{\star \star}\end{array}$ & $\begin{array}{l}-0.083 \\
-2.88^{\star \star}\end{array}$ & $\begin{array}{l}-0.080 \\
-2.78^{\star \star}\end{array}$ \\
\hline RESTATE_DIFF & & $\begin{array}{c}0.770 \\
10.12^{\star \star}\end{array}$ & & & $\begin{array}{l}0.784 \\
9.46^{\star \star}\end{array}$ & \\
\hline ABS_RESTATE_DIFF & & & $\begin{array}{l}-0.106 \\
-1.68\end{array}$ & & & $\begin{array}{l}-0.103 \\
-1.55\end{array}$ \\
\hline Other control variables & Yes & Yes & Yes & Yes & Yes & Yes \\
\hline Observations & 57 & 57 & 57 & 57 & 57 & 57 \\
\hline
\end{tabular}

Panel E. Repeat Table 10 for FoFs

\begin{tabular}{|c|c|c|c|c|c|c|}
\hline & \multicolumn{2}{|c|}{ All } & \multicolumn{2}{|c|}{ Unrestricted } & \multicolumn{2}{|c|}{ Restricted } \\
\hline & 1 & 2 & 3 & 4 & 5 & 6 \\
\hline PERF & $\begin{array}{l}0.0027 \\
6.94^{\star \star}\end{array}$ & $\begin{array}{l}0.0020 \\
5.45^{\star \star}\end{array}$ & $\begin{array}{l}0.0037 \\
7.62^{\star \star}\end{array}$ & $\begin{array}{l}0.0022 \\
4.78^{* *}\end{array}$ & $\begin{array}{l}0.0003 \\
0.52\end{array}$ & $\begin{array}{l}0.0008 \\
1.19\end{array}$ \\
\hline DELAY & & $\begin{array}{c}-0.0073 \\
7.35^{\star \star}\end{array}$ & & $\begin{array}{c}-0.0084 \\
6.72^{\star \star}\end{array}$ & & $\begin{array}{c}-0.0012 \\
0.68\end{array}$ \\
\hline PERF $\times$ DELAY & & $\begin{array}{c}-0.0035 \\
9.15^{\star \star}\end{array}$ & & $\begin{array}{c}-0.0035 \\
7.92^{* \star}\end{array}$ & & $\begin{array}{c}-0.0014 \\
1.75\end{array}$ \\
\hline $\ln (1+A G E)$ & $\begin{array}{c}-0.0130 \\
4.25^{\star *}\end{array}$ & $\begin{array}{c}-0.0138 \\
4.51^{\star \star}\end{array}$ & $\begin{array}{c}-0.0045 \\
1.10\end{array}$ & $\begin{array}{c}-0.0059 \\
1.47\end{array}$ & $\begin{array}{c}-0.0245 \\
4.97^{\star \star}\end{array}$ & $\begin{array}{c}-0.0246 \\
4.97^{\star \star}\end{array}$ \\
\hline $\ln (1+\mathrm{AUM})$ & $\begin{array}{l}-0.0207 \\
11.41^{\star \star}\end{array}$ & $\begin{array}{l}-0.0206 \\
11.38^{\star \star}\end{array}$ & $\begin{array}{l}-0.0279 \\
10.02^{\star \star}\end{array}$ & $\begin{array}{c}-0.0275 \\
9.89^{* *}\end{array}$ & $\begin{array}{c}-0.0115 \\
5.16^{\star \star}\end{array}$ & $\begin{array}{r}-0.0115 \\
5.18^{\star \star}\end{array}$ \\
\hline $\begin{array}{l}\text { Observations } \\
R^{2}\end{array}$ & $\begin{array}{c}92,912 \\
0.14\end{array}$ & $\begin{array}{c}92,912 \\
0.14\end{array}$ & $\begin{array}{c}58,482 \\
0.21\end{array}$ & $\begin{array}{c}58,482 \\
0.21\end{array}$ & $\begin{array}{c}34,430 \\
0.07\end{array}$ & $\begin{array}{c}34,430 \\
0.07\end{array}$ \\
\hline $\begin{array}{l}\text { Fund dummies } \\
\text { Month dummies } \\
\text { Level of clustering }\end{array}$ & $\begin{array}{l}\text { Yes } \\
\text { Yes } \\
\text { Fund }\end{array}$ & $\begin{array}{l}\text { Yes } \\
\text { Yes } \\
\text { Fund }\end{array}$ & $\begin{array}{l}\text { Yes } \\
\text { Yes } \\
\text { Fund }\end{array}$ & $\begin{array}{l}\text { Yes } \\
\text { Yes } \\
\text { Fund }\end{array}$ & $\begin{array}{l}\text { Yes } \\
\text { Yes } \\
\text { Fund }\end{array}$ & $\begin{array}{l}\text { Yes } \\
\text { Yes } \\
\text { Fund }\end{array}$ \\
\hline
\end{tabular}


Panels B-D of Table 11 show that the evidence of predictability is indeed much stronger among FoFs. As shown in Panel B, the Q1-Q5 style-adjusted return spread averages $0.42 \%$ per month, which is nearly double the $0.23 \%$ figure reported in Table 7 for the main sample that excludes FoFs. As discussed in our analysis of stand-alone hedge funds, a manager's timeliness in reporting to a public database could represent an aspect of operational risk that is predictive of the fund's performance. In the case of an FoF, however, reporting delays can reflect the operational risk of the FoF but also that of its underlying hedge fund investments.

In Panel $\mathrm{C}$ of Table 11, model 2 shows that a 1-standard-deviation increase in HIST_REPLAG is associated with a decrease in future returns of 6.6 bps per month. In comparison, we recall that the same estimate is 3.9 bps for our main sample that excludes FoFs. Panel D shows that the predictability of reporting lags for FoF performance withstands our more stringent controls for asset illiquidity exposure (RESTATE_DIFF) and the replacement of fund reporting lags with those of other funds in the same family.

Last, in Panel E of Table 11, we repeat our analysis of fund investor flows for the FoF sample. The evidence here reemphasizes our findings for the main sample: Reporting delays are associated with lower investor flows and a weaker response of flows to past performance. Taken together, our analysis of the holdout sample of FoFs lends further support to our findings for the main sample of hedge funds.

\section{Conclusions}

We decipher over 5 years' worth of daily voluntary disclosures by hedge fund managers to study how information flows from managers to fund investors and the broader public market. Our empirical results strongly indicate that managers tend to be strategic in the timing of disclosures to public databases. Information about a fund's monthly performance is conveyed approximately 2 weeks after month-end, but the lag can be significantly larger when performance is worse. We also find significantly longer reporting lags among funds that display greater operational risk and suspicious patterns in returns, suggesting that delay may be part of the misreporting mechanism. Delays are also longer when fund investors face greater restrictions on share redemptions, and therefore plausibly when assets are illiquid and the costs from nondisclosure are low.

Managers may delay reporting poor performance because, in part, they hope that it will be offset by better subsequent returns. Indeed, a significant fraction of hedge fund returns are reported simultaneously in return clusters, and clusters tend to feature strong reversals of poor performance. This finding has important implications for performance measurement because it suggests that many periods of poor performance are observable only if the manager subsequently recovers at least part of his or her losses.

We find that an understanding of hedge fund manager reporting behavior potentially carries significant investment value for hedge fund investors. The reason is that reporting lags may be symptomatic of operational risk and poorer management and, hence, predictive of poor future performance. Our results indicate that 
funds that are (historically) less timely (relative to peers) tend to significantly underperform more timely funds in subsequent months. The predictability we document corresponds to a quarterly rebalancing strategy in "real time" and is present among funds with relatively few restrictions on investor liquidity. This suggests that data repositories can enhance their value to investors by providing information about when managers make voluntary disclosures about fund performance.

We do not claim, however, to have a clear identification strategy to discern information channels between fund managers and existing investors beyond the manager's voluntary disclosures to public databases. Nevertheless, we find that delays in disclosure are associated with significantly lower net fund flows, consistent with investors responding negatively to such delays. At the same time, greater reporting lags are associated with a significantly lower flow-performance sensitivity. We show that a fund with a sufficiently poor performance may be better off by delaying information disclosure. In particular, our regression estimates suggest that reporting delays are justified for a manager with recent performance less than or equal to 1 standard deviation below the mean.

Our results are relevant to potential regulatory changes to the disclosure requirements of investment managers, especially hedge funds. For example, requiring managers to report performance in a timely fashion could potentially improve price discovery in the market for hedge fund managers, subject, of course, to a manager's incentive to produce reliable information without distortion. More generally, the results provide an interesting illustration of the flow of information, and its problems and drawbacks, when the provision of performance information is largely discretionary.

\section{References}

Acharya, V. V.; P. M. DeMarzo; and I. Kremer. "Endogenous Information Flows and the Clustering of Announcements.” American Economic Review, 101 (2011), 2955-2979.

Agarwal, V.; N. Daniel; and N. Naik. "Flows, Performance, and Managerial Incentives in Hedge Funds." Working Paper, George State University (2004).

Agarwal, V.; N. Daniel; and N. Naik. "Role of Managerial Incentives and Discretion in Hedge Fund Performance." Journal of Finance, 64 (2009), 2221-2256.

Agarwal, V.; N. Daniel; and N. Naik. "Do Hedge Funds Manage Their Reported Returns?" Review of Financial Studies, 24 (2011), 3281-3320.

Agarwal, V.; V. Fos; and W. Jiang. "Inferring Reporting-Related Biases in Hedge Fund Databases from Hedge Fund Equity Holdings.” Management Science, 59 (2013), 1271-1289.

Agarwal, V.; W. Jiang; Y. Tang; and B. Yang. "Uncovering Hedge Fund Skill from the Portfolio Holdings They Hide." Journal of Finance, 68 (2013), 739-783.

Agarwal, V., and J. Kale. "On the Relative Performance of Multi-Strategy and Funds of Hedge Funds." Journal of Investment Management, 5 (2007), 41-63.

Aggarwal, R., and P. Jorion. "Hidden Survivorship Bias in Hedge Fund Returns." Financial Analysts Journal, 66 (2010), 69-74.

Aggarwal, R., and P. Jorion. “Is There a Cost to Transparency?” Financial Analysts Journal, 68 (2012), $108-123$.

Aiken, A.; C. Clifford; and J. Ellis. "Out of the Dark: Hedge Fund Reporting Biases and Commercial Databases.” Review of Financial Studies, 26 (2013), 208-243.

Ang, A.; M. Rhodes-Kropf; and R. Zhao. "Do Funds-of-Funds Deserve Their Fees-on-Fees?" Journal of Investment Management, 6 (2008), 34-58.

Aragon, G. O. "Share Restrictions and Asset Pricing: Evidence from the Hedge Fund Industry." Journal of Financial Economics, 83 (2007), 33-58.

Aragon, G. O.; M. Hertzel; and Z. Shi. "Why Do Hedge Funds Avoid Disclosure? Evidence from Confidential 13F Filings." Journal of Financial and Quantitative Analysis, 48 (2013), 1499-1518. 
Bali, T.; S. Brown; and M. Caglayan. "Do Hedge Funds' Exposures to Risk Factors Predict Their Future Returns?" Journal of Financial Economics, 101 (2011), 36-68.

Bali, T.; S. Brown; and M. Caglayan. "Systematic Risk and the Cross Section of Hedge Fund Returns." Journal of Financial Economics, 106 (2012), 114-131.

Bali, T.; S. Brown; and M. Caglayan. "Economic Uncertainty and the Cross-Section of Hedge Fund Returns.” Working Paper, Georgetown University (2013).

Baquero, G., and M. Verbeek. "A Portrait of Hedge Fund Investors: Flows, Performance and Smart Money.” Working Paper, Erasmus University Rotterdam (2009).

Bollen, N., and V. Pool. "Conditional Return Smoothing in the Hedge Fund Industry." Journal of Financial and Quantitative Analysis, 43 (2008), 267-298.

Bollen, N., and V. Pool. "Do Hedge Fund Managers Misreport Returns? Evidence from the Pooled Distribution.” Journal of Finance, 64 (2009), 2257-2288.

Bollen, N., and V. Pool. "Suspicious Patterns in Hedge Fund Returns and the Risk of Fraud." Review of Financial Studies, 25 (2012), 2673-2702.

Boyson, N. "Do Hedge Funds Exhibit Performance Persistence? A New Approach." Financial Analysts Journal, 64 (2008), 15-26.

Brown, S.; W. Goetzmann; and B. Liang. "Fees on Fees in Funds of Funds." Journal of Investment Management, 2 (2004), 39-56.

Brown, S.; W. Goetzmann; B. Liang; and C. Schwarz. "Mandatory Disclosure and Operational Risk: Evidence from Hedge Fund Registration.” Journal of Finance, 63 (2008), 2785-2815.

Brown, S.; W. Goetzmann; B. Liang; and C. Schwarz. "Estimating Operational Risk for Hedge Funds: The Score." The Financial Analysts Journal, 65 (2009), 43-53.

Brown, S.; W. Goetzmann; B. Liang; and C. Schwarz. "Trust and Delegation.” Journal of Financial Economics, 103 (2012), 221-234.

Cassar, G., and J. Gerakos. "Hedge Funds: Pricing Controls and the Smoothing of Reported Returns." Review of Financial Studies, 24 (2011), 1698-1734.

Diamond, D. W. "Optimal Release of Information by Firms." Journal of Finance, 40 (1985), 1071-1094.

Ding, B.; M. Getmansky; B. Liang; and R. Wermers. "Share Restrictions and Investor Flows in the Hedge Fund Industry." Working Paper, University of Massachusetts at Amherst (2009).

Evans, R. "Mutual Fund Incubation.” Journal of Finance, 65 (2010), 1581-1611.

Fama, E., and J. MacBeth. "Risk, Return, and Equilibrium: Empirical Tests." Journal of Political Economy, 81 (1973), 607-636.

Fung, W., and D. Hsieh. "Performance Characteristics of Hedge Funds and Commodity Funds: Natural vs. Spurious Biases.” Journal of Financial and Quantitative Analysis, 35 (2000), 291-307.

Fung, W., and D. Hsieh. "The Risk in Hedge Fund Strategies: Theory and Evidence from Trend Followers." Review of Financial Studies, 14 (2001), 313-341.

Fung, W., and D. Hsieh. "Hedge Fund Benchmarks: A Risk-Based Approach." Financial Analysts Journal, 60 (2004), 65-80.

Fung, W.; D. Hsieh; N. Naik; and T. Ramadorai. "Hedge Funds: Performance, Risk, and Capital Formation." Journal of Finance, 63 (2008), 1777-1803.

Getmansky, M.; A. Lo; and I. Makarov. "An Econometric Model of Serial Correlation and Illiquidity in Hedge Fund Returns.” Journal of Financial Economics, 74 (2004), 529-609.

Goetzmann, W.; J. Ingersoll; and S. Ross. "High-Water Marks and Hedge Fund Management Contracts." Journal of Finance, 58 (2003), 1685-1717.

Grossman, S. "The Informational Role of Warranties and Private Disclosures about Product Quality." Journal of Law and Economics, 24 (1981), 461-483.

Jagannathan, R.; A. Malakhov; and D. Novikov. "Do Hot Hands Exist among Hedge Fund Managers? An Empirical Evaluation.” Journal of Finance, 65 (2010), 217-255.

Kosowski, R.; N. Naik; and M. Teo. "Do Hedge Funds Deliver Alpha? A Bayesian and Bootstrap Analysis.” Journal of Financial Economics, 84 (2007), 229-264.

Milgrom, P. R. "Good News and Bad News: Representation Theorems and Applications." Bell Journal of Economics, 12 (1981), 350-391.

Pastor, L., and R. Stambaugh. "Liquidity Risk and Expected Stock Returns." Journal of Political Economy, 111 (2003), 642-685.

Patton, A.; T. Ramadorai; and M. Streatfield. "Change You Can Believe In? Hedge Fund Data Revisions.” Journal of Finance, 70 (2013), 963-999.

Ross, S. A. "Disclosure Regulation in Financial Markets: Implications of Modern Finance Theory and Signaling Theory.” In Issues in Financial Regulation, F. K. Edwards, ed. New York: McGraw-Hill (1979).

Sadka, R. "Liquidity Risk and the Cross-Section of Hedge-Fund Returns." Journal of Financial Economics, 98 (2010), 54-71. 
Straumann, D. "Measuring the Quality of Hedge Fund Data." RiskMetrics Journal, Winter (2008), 65-93.

Verrecchia, R. E. "Discretionary Disclosure.” Journal of Accounting and Economics, 5 (1983), $365-380$.

Zoromé, A. "Concept of Offshore Financial Centers: In Search of an Operational Definition.” Working Paper, International Monetary Fund (2007). 